\title{
Present and future evolution of advanced breast cancer therapy
}

\author{
Ricardo H Álvarez*
}

\begin{abstract}
Although the introduction of novel therapies and drug combinations has improved the prognosis of metastatic breast cancer, the disease remains incurable. Increased knowledge of the biology and the molecular alterations in breast cancer has facilitated the design of targeted therapies. These agents include receptor and nonreceptor tyrosine kinase inhibitors (epidermal growth factor receptor family), intracellular signaling pathways (phosphatidylinositol-3-kinase, AKT, mammalian target of rapamycin) angiogenesis inhibitors and agents that interfere with DNA repair (poly(ADP-ribose) polymerase inhibitors). In the present review, we present the most promising studies of these new targeted therapies and novel combinations of targeted therapies with cytotoxic agents.
\end{abstract}

\section{Introduction}

Current research in breast cancer is being guided by the discovery of multiple targets cells or tissues that have receptors for a particular hormone or drug. These targets are leading to treatments more sophisticated than conventional cytotoxic chemotherapy or hormone-based therapy. Targeting of human epidermal growth factor receptor 2 (HER2) with trastuzumab and of vascular endothelial growth factor (VEGF) with bevacizumab in combination with chemotherapy has proven to be a milestone in molecular targeted therapy for breast cancer.

As many novel targets are being discovered, multiple approaches to anticancer therapy are emerging in the literature. These approaches, referred to as targeted therapies, consist of targeting the malignant cell signal transduction machinery, including the crucial processes involved in cell invasion, cell metastasis, apoptosis, the cell cycle, and tumor-related angiogenesis. Among these

*Correspondence: ralvarez@mdanderson.org

Department of Breast Medical Oncology, The University of Texas M.D. Anderson Cancer Center, 1155 Herman P. Pressler, CPB5.3458, Houston, TX 77030-3721, USA therapies, a class of compounds that has shown great promise is one that targets tyrosine kinases, which are carried by small molecules or monoclonal antibodies. Intrinsic and acquired resistance to endocrine and/or cytostatic treatments, however, is still a common feature that limits the benefits for these novel therapeutic strategies. Clinical trials of endocrine or cytotoxic therapies, combined with growth factor pathway inhibitors or their downstream signaling elements, are therefore warranted. In the present review, we describe the most promising studies using these new molecular agents and their novel combinations with traditional cytotoxic agents in targeted therapies.

\section{Preferred treatment schemes: sequential single-agent chemotherapy or combination chemotherapy}

Breast cancer is a world health problem, and in the United States this disease is the second most common cause of cancer death in women [1]. Although breast cancer is among the most chemosensitive of the solid tumors, important improvements in survival have been achieved during the past two decades with the introduction of the new agents [1]. For patients with estrogen receptor (ER)-positive metastatic breast cancer (MBC) without visceral crisis, hormone therapy has been the preferred treatment option. The optimal timing for initiation of hormone therapy or chemotherapy, however, needs to be individualized.

Several randomized phase III studies have compared single-agent chemotherapy versus combination chemotherapy, and most have reported improved response rates and time to disease progression but minimal survival benefit. A systematic review published a decade ago, which included 15 randomized trials in the pre-taxane era, concluded that multidrug combination chemotherapy was superior to single-agent chemotherapy [2]. More recently, a meta-analysis of 37 randomized trials, which included new drugs for breast cancer treatment, showed again that a combination of chemotherapeutic agents increased the response rate (odds ratio, 1.28; 95\% confidence interval (CI), 1.15 to $1.42 ; P<0.00001)$ and improved the time to tumor progression (hazard ratio 
(HR), 0.78 ; $95 \% \mathrm{CI}, 0.73$ to $0.83 ; P<0.00001$ ), with a $12 \%$ of increase in overall survival (OS) [3].

\section{Chemotherapy}

Standard of care: anthracyclines and taxanes

Anthracyclines and taxanes are the most active cytotoxic drugs for the treatment of breast cancer. In the adjuvant setting, the pivotal role of anthracycline-based chemotherapy bas been established in an overview of successive randomized trials by the Early Breast Cancer Trialists' Collaborative Group [4]. Concerns have been voiced about cardiac toxicity and potential leukemogenicity with use of anthracyclines. In the metastatic setting, the incidence of cardiac dysfunction has been related to the dose and schedule of anthracyclines [5]. Cardiac toxicity with use of anthracyclines has been associated with congestive heart failure. The risk of developing congestive heart failure is also known to increase with concomitant administration of other cytotoxic drugs, such as cyclophosphamide. Doxorubicin given at 240 to $360 \mathrm{mg} / \mathrm{m}^{2}$ has reduced the incidence of congestive heart failure to around 1.6 to $2.1 \%[5,6]$. Data from a study of long-term survivors of childhood cancer, however, indicated that no true threshold can be determined for anthracyclinerelated cardiotoxicity and that the symptoms of congestive heart failure become apparent years after use of the drug [7]. Several reports have shown that the incidence of cardiac toxicity is low in women who received adjuvant anthracyclines $[8,9]$.

The advent of taxanes provided a novel option for chemotherapy, and an early single-agent randomized trial showed that results for taxanes were similar to or perhaps slightly better than those for counterpart anthracyclines in the metastatic setting [10]. Few studies have been conducted, however, comparing anthracycline-containing and taxane-containing regimens. In one such study, Jones and colleagues suggested that docetaxel plus cyclophosphamide was superior to Adriamycin plus cyclophosphamide in the adjuvant treatment of breast cancer [11]. Comparisons of docetaxel plus cyclophosphamide with Adriamycin plus cyclophosphamide represent comparisons of first-generation regimens with third-generation regimens. To date, the data are insufficient to recommend replacing anthracyclines in the adjuvant treatment of breast cancer [12].

\section{Newly approved chemotherapy agents: epothilones and ixabepilone}

Microtubules play a crucial role in diverse cellular function including growth, motility, trafficking of vesicles, and cellular shape maintenance. The mitotic spindles - where chromosomes are attached and then separated - are composed of both $\alpha$-tubulin and $\beta$-tubulin subunits, and the process of polymerization and depolymerization of the microtubule is very complex and dynamic. Two families of chemotherapeutic agents, the vinca alkaloids and taxanes, interact with microtubules. Among the taxane family, paclitaxel and docetaxel are the most widely used agents in the metastatic setting, with response rates of 32 to $68 \%$ when used as single agents [13]. Although the introduction of these agents marked a significant advance for the treatment of cancer, their clinical utility is often limited by the development of drug resistance. This resistance can be intrinsic or acquired after the tumor is exposed to certain chemotherapeutic agents. One common mechanism of tumor resistance occurs through expression of multidrug-resistance proteins (p-glycoprotein and MDR-1). These proteins build up efflux pumps, which prevent a therapeutic concentration of drug from accumulating in tumor cells. In antimicrotubular agents, such as the taxanes, additional mechanisms of tumor resistance can arise that prevent interaction with their target, $\beta$-tubulin.

Epothilones are naturally occurring macrolides that share a similar mechanism of action with taxanes. These agents induce microtubule polymerization at submicromolar concentrations [14]. In the preclinical setting, epothilones possess potent antiproliferative activity in various tumor cell lines, particularly in the setting of taxane resistance [15-17]. Epothilones and paclitaxel compete for the same binding pocket on $\beta$-tubulin; however, epothilones and the taxanes bind to different sites on $\beta$-tubulin. Significantly, epothilones have low susceptibility to multiple mechanisms of tumor resistance, including overexpression of MDR-1, p-glycoprotein, and tubulin mutations [18-20]. The epothilones and their analogues therefore probably represent an important treatment option for patients with cancer, including those whose disease is resistant to other currently available treatments.

Currently, there are five epothilones being investigated in clinical trials: patupilone (epothilone B, EPO906), ixabepilone (aza-epothilone B, BMS-247550), BMS-310705 (a water-soluble semisynthetic analog of epothilone B), KOS-852 (epothilone D), and ZK-EPO [21]. Ixabepilone has been the most extensively studied and is the only epothilone approved by the US Food and Drug Administration for the treatment of cancer. Ixabepilone has a broad spectrum of activity against multiple cell lines and in vivo in animal models. Lee and colleagues tested ixabepilone in multiple human cancer cell lines, finding that in 18 out of 21 lines the half-maximal inhibitory concentration $\left(\mathrm{IC}_{50}\right)$ values were 1.4 to $6 \mathrm{nM}$ [20].

\section{Clinical activity}

To date, six relevant phase II clinical studies and one phase III clinical study have evaluated ixabepilone in patients with anthracycline-pretreated or taxane-pretreated 
or taxane-resistant advanced breast cancer (Table 1). Two phase II clinical studies in patients treated with anthracyclines revealed overall response rates (ORRs) of $41.5 \%$ [22] and 57\% [23]. More importantly, in patients resistant to anthracyclines, taxanes, and/or capecitabine, singleagent ixabepilone showed an ORR of $11 \%$ in 113 evaluable patients, $50 \%$ of whom had stable disease (SD) [24]. Based on results from a pivotal phase III study [25], ixabepilone in combination with capecitabine was approved for the treatment of locally advanced breast cancer or MBC after failure of a taxane and an anthracycline. Ixabepilone monotherapy is indicated after failure of a taxane, anthracycline, and capecitabine, based on the results from the phase II study in this patient population [24].

\section{Targeted therapy}

\section{Anti-HER2 therapies: newer HER2-targeted agents}

Epidermal growth factor receptor (EGFR) is a receptor tyrosine kinase frequently expressed in epithelial tumors. A wide variety of cellular functions are modulated by the four members of the EGFR family, which play a major role in promoting breast cancer cell proliferation and malignant growth [26]. EGFR is thus an attractive target for therapeutic intervention. This receptor family comprises four homologous receptors: EGFR (ErbB1/EGFR/ HER1), ErbB2 (HER2/neu), ErbB3 (HER3), and ErbB4 (HER4). At least six different ligands, known as epidermal growth factor-like ligands, bind to EGFR [27]. After ligand binding, the ErbB receptor is activated by dimerization between two identical receptors (homodimerization) or between different receptors of the same family (heterodimerization) [28]. After receptor dimerization, an activation cascade of multiple protein kinase activity and tyrosine autophosphorylation occurs, phosphorylating several intracellular substrates including RasRaf-mitogen-activated protein kinase, phosphatidylinositol3-kinase (PI3K)-Akt, and other important signaling that regulates apoptosis and cellular proliferation pathways $[29,30]$.

In breast cancer, EGFR and HER2 are frequently overexpressed and are associated with aggressive clinical behavior and poor outcome [31,32]; however, the outcome for patients with these highly aggressive tumors has markedly improved with the development of anti-HER2 therapies. Trastuzumab is a recombinant humanized monoclonal antibody that binds with high affinity to the extracellular domain of HER2 and inhibits proliferation in human tumor cells that overexpress HER2 [33]. Trastuzumab was the first HER2-targeted therapy approved by the US Food and Drug Administration in 1998 for the treatment of HER2-overexpression MBC [34]. Several clinical trials subsequently established the fact that the addition of trastuzumab to adjuvant chemotherapy (either in sequence or in combination) resulted in significant improvements in disease-free and OS rates in patients with early-stage HER2-overexpression MBC [35-37]. Although trastuzumab represents the first success in targeted therapy for breast cancer, onethird of patients are resistant to the treatment and many questions remain about the mechanism of activity. Both antibody-mediated inhibition of HER2 and use of receptor tyrosine kinase inhibitors (TKIs) are proven beneficial strategies for tumors with HER2 overexpression.

Small-molecule TKIs compete with ATP for binding at the EGFR catalytic kinase domain, preventing signal transduction of both the Ras-RAF1-mitogen-activated protein kinase and PI3K pathways and leading to increased apoptosis and decreased cellular proliferation. These compounds may be reversible (that is, lapatinib, gefitinib, or erlotinib) or irreversible (carnetinib or neratinib). With the exception of gefitinib and erlotinib, which are considered pure EGFR inhibitors, the remaining TKIs are characterized by multiple kinase inhibitors [38]. The promiscuous nature of the multiple inhibitors has the potential to contribute to increased toxicity.

\section{Epidermal growth factor family inhibitors Gefitinib}

Gefitinib (formerly known as ZD1839) - a pure EFGR inhibitor - is a small-molecule anilinoquinazoline that reversibly inhibits EGFR tyrosine kinase autophosphorylation and inhibits downstream signaling [39]. In tumor cell lines, gefitinib inhibits the growth of cells that express high levels of EGFR. Gefitinib has been shown to block EGFR downstream signal transduction pathways; this induces cell cycle arrest, which leads to accumulation of the cyclin-dependent kinase 2 inhibitor p27 KIP1 and marked accumulation of hypophosphorylated $\mathrm{Rb}$ protein, which leads to $\mathrm{G}_{1}$ arrest [40].

Multiple phase I and phase II studies using gefitinib as a single agent or combined with chemotherapy in breast cancer patients have been completed. Gefitinib as a single agent resulted in minimal clinical benefit $(\mathrm{CB})$, and the nonrandomized combination studies showed that gefitinib did not significantly increase disease-free survival or ORR. A preliminary exploratory analysis of two randomized, phase II, placebo-controlled trials comparing anastrozole or tamoxifen with or without gefitinib was published [41]. In both trials, endocrine therapy-naïve patients experienced prolonged progression-free survival (PFS) with hormone therapy plus gefitinib.

\section{Erlotinib}

Erlotinib (formerly known as OSI-774) - a pure EFGR inhibitor - is a small-molecule quinazolinamine that reversibly inhibits EGFR tyrosine kinase and prevents receptor autophosphorylation [42]. Several trials of 
Table 1. Clinical efficacy of ixabepilone in locally advanced and metastatic breast cancer

\begin{tabular}{|c|c|c|c|c|c|c|c|}
\hline $\begin{array}{l}\text { Author and } \\
\text { reference }\end{array}$ & Trial design & $\begin{array}{c}\text { Number } \\
\text { of } \\
\text { patients }\end{array}$ & $\begin{array}{l}\text { Patient } \\
\text { population }\end{array}$ & Dose schedule & ORR & PFS & Toxicity grade $3 / 4$ \\
\hline Roche et al. [22] & $\begin{array}{l}\text { Single arm, } \\
\text { phase II }\end{array}$ & 65 & $\begin{array}{l}\text { First-line MBC - } \\
\text { prior adjuvant } \\
\mathrm{A}(100 \%) \text { and T } \\
(17 \%)\end{array}$ & $\begin{array}{l}\text { Ixa } 40 \mathrm{mg} / \mathrm{m}^{2} \\
\text { every } 3 \text { weeks }\end{array}$ & $41.5 \%$ & $\begin{array}{l}\text { TTP } 4.8 \text { months ( } 4.2 \\
\text { to } 7.6 \text { ), median OS } \\
22 \text { months ( } 15.6 \\
\text { to } 27 \text { ) }\end{array}$ & $\begin{array}{l}\text { Neutropenia 58\%, } \\
\text { PN 28\% }\end{array}$ \\
\hline $\begin{array}{l}\text { Denduliri et al. } \\
\text { [23] }\end{array}$ & $\begin{array}{l}\text { Single arm, } \\
\text { phase II }\end{array}$ & 23 & First-line MBC & $\begin{array}{l}\text { Ixa } 6 \mathrm{mg} / \mathrm{m}^{2} / \text { day } \\
\text { on days } 1 \text { to } 5 \\
\text { every } 3 \text { weeks }\end{array}$ & $57 \%$ & TTP 5.5 months & $\begin{array}{l}\text { Neutropenia } \\
22 \% \text {, fatigue 13\%, } \\
\text { nausea 9\% }\end{array}$ \\
\hline Perez et al. [24] & $\begin{array}{l}\text { Single agent, } \\
\text { phase II }\end{array}$ & 126 & $\begin{array}{l}\text { Refractory to T, A, } \\
\text { and } C P C\end{array}$ & $\begin{array}{l}\text { Ixa } 40 \text { mg/m² } \\
\text { every } 3 \text { weeks }\end{array}$ & $\begin{array}{c}11.5 \% \text { (95\% Cl: } \\
6.3 \text { to } 18.9 \text { months) }\end{array}$ & $\begin{array}{c}3.1 \text { months } \\
\text { (2.7 to } 4.2 \text { months) }\end{array}$ & Neutropenia 54\% \\
\hline $\begin{array}{l}\text { Bunnell et al. } \\
\text { [139] }\end{array}$ & $\begin{array}{l}\text { Single arm, } \\
\text { phase II }\end{array}$ & 62 & $\begin{array}{l}\text { Refractory to A } \\
\text { and T (100\%) }\end{array}$ & $\begin{array}{l}\text { Ixa } 40 \mathrm{mg} / \mathrm{m}^{2} \\
\text { every } 3 \text { weeks plus } \\
\text { CPC } 1,000 \mathrm{mg} / \mathrm{m}^{2} \\
\text { twice daily for } 14 \\
\text { days }\end{array}$ & $30 \%$ & $\begin{array}{c}3.8 \text { months } \\
\text { (2.7 to } 5.6 \text { months) }\end{array}$ & $\begin{array}{l}\text { Neutropenia 69\%, } \\
\text { HFS 34\%, PN 19\% }\end{array}$ \\
\hline $\begin{array}{l}\text { Thomas et al. } \\
\text { [140] }\end{array}$ & $\begin{array}{l}\text { Single arm, } \\
\text { phase II }\end{array}$ & 49 & $\begin{array}{l}\text { Second-line, } \\
\text { third-line, or } \\
\text { fourth-line }\end{array}$ & $\begin{array}{l}\text { Ixa } 40 \text { mg/m² } \\
\text { every } 3 \text { weeks }\end{array}$ & $12 \%$ & $\begin{array}{c}\text { TTP } 2.2 \text { months, OS } \\
7.9 \text { months (6.1 to } \\
14.5 \%)\end{array}$ & $\begin{array}{l}\text { Neutropenia 55\%, } \\
\text { PN 12.2\% }\end{array}$ \\
\hline Low et al. [141] & $\begin{array}{l}\text { Single arm, } \\
\text { phase II }\end{array}$ & 37 & First-line & $\begin{array}{l}\text { Ixa } 6 \text { mg } / \mathrm{m}^{2} / \text { day } \\
\text { on days } 1 \text { to } 5 \\
\text { every } 3 \text { weeks }\end{array}$ & $22 \%$ (9.8 to $38.2 \%$ ) & TTP 2.6 months & $\begin{array}{l}\text { Neutropenia 35\%, } \\
\text { FN 14\% }\end{array}$ \\
\hline $\begin{array}{l}\text { Thomas et al. } \\
\text { [25] }\end{array}$ & $\begin{array}{l}\text { Randomized, } \\
\text { phase III }\end{array}$ & 752 & >First-line & $\begin{array}{l}\text { Ixa } 40 \mathrm{mg} / \mathrm{m}^{2} \\
\text { every } 3 \text { weeks plus } \\
\text { CPC } 2,500 \mathrm{mg} / \mathrm{m}^{2} \\
\text { for } 14 \text { days vs. CPC } \\
2,000 \mathrm{mg} / \mathrm{m}^{2} \text { for } \\
14 \text { days }\end{array}$ & $42 \%$ vs. $23 \%$ & $5.3 \%$ vs. $3.8 \%$ & $\begin{array}{l}\text { PN } 23 \% \text { vs. } 0 \% \\
\text { myalgias } 8 \% \text { vs. } \\
0.3 \% \text {, asthenia } \\
7.8 \% \text { vs. } 0.8 \%\end{array}$ \\
\hline
\end{tabular}

A, anthracyclines; $\mathrm{Cl}$, confidence interval; $\mathrm{CPC}$, capecitabine; FN, febrile neutropenia; HFS, hand-and-foot syndrome; Ixa, ixabepilone; MBC, metastatic breast cancer; ORR, overall response rate; OS, overall survival; PFS, progression-free survival; PN, peripheral neuropathy; TTP, time to tumor progression; T, taxanes.

erlotinib in combination with drugs known to be active in breast cancer were recently conducted. In a doseescalation study of erlotinib in combination with capecitabine and docetaxel in patients with $\mathrm{MBC}$, two patients had complete response and 12 patients had partial response (PR) (ORR, 67\%) [43]. The main toxic effects of the regimen consisted of skin and gastrointestinal manifestations.

Several other preliminary studies combining erlotinib with docetaxel [44], with vinorelbine plus capecitabine [45], and with bevacizumab [46] have been reported.

On the basis of data from a preclinical mouse xenograft model, a clinical trial was conducted involving patients with operable breast cancer stage I to stage IIIA. Fiftytwo patients received erlotinib at $150 \mathrm{mg} /$ day orally for 6 to 14 days before surgery [47]. A reduction in Ki67 expression, a surrogate marker of proliferation, was demonstrated in ER-positive tumors but not in those that overexpressed HER2 or in those with triple receptornegative (TRN) breast cancer.

\section{Trastuzumab-DM1}

Trastuzumab-DM1 was the first antibody-drug conjugate based on trastuzumab, which consists of trastuzumab linked to an antimicrotubule drug, maytansine (also known as DM1). The potential advantage of this conjugate is that trastuzumab targets DM1 specifically into tumor tissues, which may reduce toxicity.

In addition, trastuzumab has its own anticancer activity. Trastuzumab-DM1 showed activity in a xenograft model of HER2-positive, trastuzumab-resistant tumors [48]. A phase I study of trastuzumab-DM1 in heavily pretreated patients with HER2-overexpressing MBC showed clinical activity, with thrombocytopenia as the dose-limiting toxicity (DLT), at a dosage of $4.8 \mathrm{mg} / \mathrm{kg}$ every 3 weeks. The recommended dosage for phase II studies was $3.6 \mathrm{mg} / \mathrm{kg}$ every 3 weeks [49]. A recent preliminary report of a phase II study of trastuzumab-DM1 in 112 patients with HER2-overexpressing MBC in whom treatment with trastuzumab, lapatinib, or both had failed showed promising activity, with an independent review panel confirming an ORR of $25 \%$ (28 patients) and a CB rate of $34 \%$ (38 patients) [50].

Two phase III studies of trastuzumab-DM1 are ongoing. One trial is testing the activity of trastuzumab-DM1 versus standard therapy with lapatinib-capecitabine as the second-line therapy for patients with HER2-positive MBC. The other ongoing study is testing docetaxel plus trastuzumab versus single-agent trastuzumab-DM1 as the first-line therapy for HER2-positive MBC. 


\section{Cetuximab}

Cetuximab (formerly known as C225) is a recombinant chimeric human murine $\operatorname{IgG}_{1}$ antibody that binds to the extracellular domain of the EGFR [51]. Cetuximab was approved for use in patients with EGFR-expressing metastatic colorectal cancer refractory to irinotecanbased chemotherapy [52]. A phase I dose-escalation study of cetuximab and paclitaxel in patients with MBC showed that two out of six patients in the second cohort (cetuximab at $100 \mathrm{mg} / \mathrm{m}^{2}$ ) developed DLT effects in the form of grade 3 rash. Ten patients were evaluable for response; two of them experienced SD, and eight had progressive disease [53].

Preliminary results were reported from a randomized trial in which patients with TRN MBC refractory to between one and three lines of chemotherapy were randomly assigned to carboplatin plus cetuximab versus cetuximab alone [54]. Cetuximab alone was well tolerated, with a very modest ORR of $6 \%$. The carboplatin plus cetuximab combination arm achieved an ORR of $18 \%$ and $\mathrm{CB}$ of $27 \%$.

A preliminary report in patients with $\mathrm{MBC}$ treated with irinotecan plus carboplatin versus the same regimen plus cetuximab showed that cetuximab did not improve antitumor activity, PFS, or OS, but did increase toxicity [55]. On subset analysis, however, the addition of cetuximab increased the ORR associated with irinotecan plus carboplatin in TRN breast cancer.

\section{Dual EGFR and HER2 inhibitors \\ Lapatinib}

Lapatinib (formerly known as GW572016) is currently the most advanced oral selective dual-EGFR/HER2 reversible inhibitor in terms of clinical development in breast cancer. The rationale for developing this dual EGFR/HER2 TKI was to sustain synergistic inhibition of cancer cells by simultaneously targeting receptors in both cell lines, resulting in more potent inhibition in cell growth than could be achieved by targeting either EGFR or HER2 alone [56]. One important characteristic of lapatinib, compared with other selective EGFR TKIs such as erlotinib and gefitinib, is a slower dissociation rate from EGFR, resulting in a prolonged effect at the downregulated target site [57]. In tumor cell lines and xenograft models, lapatinib has inhibited EGFR and pErbB2, p-Erk1/2, p-AKT, and cyclin D [58,59], and this effect was dose and time dependent.

In a phase II study, 229 patients with HER2-amplified $(n=140)$ or HER2-negative $(n=89)$ triple-refractory disease (to anthracyclines, taxanes, and capecitabine) received lapatinib at $1,500 \mathrm{mg} /$ day as monotherapy [60]. Patients with HER2 amplification had a $4.3 \%$ ORR by investigator review and a $1.4 \%$ ORR by independent review. The median PFS was similar in both patient groups, and 6\% of HER2-amplified patients derived CB from lapatinib. Grade 3 and grade 4 toxic effects included diarrhea (54\%), rash $(30 \%)$, and nausea $(24 \%)$. In this group of heavily pretreated patients $(76 \%$ of whom received four or more lines of prior therapy), lapatinib had modest activity in HER2-overexpressed MBC.

\section{Lapatinib in metastatic breast cancer}

Lapatinib was approved by the US Food and Drug Administration in 2007 for use in combination with capecitabine for treatment of HER2-overexpressed MBC that had progressed with standard treatment [61]. The study was designated to compare time to tumor progression between two arms, and the secondary end point was OS. Patients were randomly assigned to receive either lapatinib $(1,250 \mathrm{mg} /$ day orally for 14 days, followed by 1 week of rest) or a combination of lapatinib and capecitabine $\left(2,000 \mathrm{mg} / \mathrm{m}^{2} /\right.$ day orally for 14 days, followed by 1 week of rest).

The study was closed prematurely after the first interim analysis, when 321 patients had been accrued, because results showed that the addition of lapatinib to capecitabine was associated with a $51 \%$ risk reduction of disease progression ( $\mathrm{HR}, 0.49$; $95 \% \mathrm{CI}, 0.34$ to 0.71 ; $P<0.001)$. The median time to tumor progression was 8.4 months for the combination arm and 4.4 months for the monotherapy arm. The ORR was $22.5 \%$ for the combination arm versus $14.3 \%$ for the monotherapy arm $(P=0.113)$. Toxic effects were similar in both arms. The most common adverse effects for the combination versus the monotherapy were diarrhea ( $58 \%$ vs. $38 \%$ ), hand-foot syndrome ( $43 \%$ vs. $34 \%)$, and rash ( $34.5 \%$ vs. $30 \%)$. In the monotherapy group 11 women had progressive central nervous system metastasis, compared with four women in the combination therapy group. This difference was not statistically significant $(P=0.10)$. Cardiotoxicity was observed in the combination arm: four patients experienced cardiac events related to treatment and fully recovered. In the capecitabine monotherapy group, one patient experienced a cardiac event unrelated to treatment, which remained unresolved.

\section{Lapatinib in combination with trastuzumab}

A preclinical study demonstrated synergistic interaction between trastuzumab and lapatinib in HER2-overexpressed breast cancer cells lines and tumor xenografts [62]. A preliminary report presented at the American Society of Clinical Oncology 2008 Annual Meeting revealed that the addition of trastuzumab to lapatinib, compared with lapatinib alone, significantly improved PFS and CB [63]. The large, ongoing Aphrodite trial has a target population of 8,000 patients with HER2overexpressed MBC. In this four-treatment-arm randomized trial, both trastuzumab and lapatinib were combined 
in the adjuvant setting. The control arm received standard trastuzumab for 1 year, and each of the three experimental arms received one of the following for 1 year: lapatinib, sequencing trastuzumab and lapatinib, or combined trastuzumab and lapatinib.

\section{Lapatinib in combination with hormonal agents}

Accumulating evidence is showing that signaling interplay occurs between the ER, HER2, EGFR, and IFG-1 receptors, affecting acquired resistance to hormonal therapies $[64,65]$. In a preclinical study, Chu and colleagues demonstrated that lapatinib can restore tamoxifen sensitivity in ER-positive, tamoxifen-resistant breast cancer models [66]. In a phase III study of letrozole with or without lapatinib in postmenopausal patients with hormone-sensitive, HER2-positive MBC, the combination resulted in improved PFS, from 3.0 to 8.2 months [67]. The ongoing LET-LOB study (Letrozole with Lapatinib) is a European phase II clinical trial of letrozole with or without lapatinib as neoadjuvant treatment in hormone-sensitive, HER2-negative operable breast cancer [68].

\section{Lapatinib in the neoadjuvant setting}

The Neo-ALTTO trial is a randomized, open-labeled, multicentric, phase III study comparing the efficacy of neoadjuvant lapatinib plus paclitaxel with that of trastuzumab plus paclitaxel and with concomitant lapatinib and trastuzumab plus paclitaxel given as neoadjuvant treatment in HER2-overexpressed operable breast cancer with a tumor diameter $>2 \mathrm{~cm}$ [69]. Preliminary results are pending.

\section{Other HER2-directed tyrosine kinase inhibitors Neratinib}

Neratinib (formerly known as HKI-272) is the next most advanced agent in clinical development after lapatinib. Neratinib is an irreversible inhibitor of HER2 and EGFR with $\mathrm{IC}_{50}$ values of $59 \mathrm{nM}$ and $92 \mathrm{nM}$, respectively [70]. In a phase I trial in solid tumors, the maximum tolerated dose was $320 \mathrm{mg}$ and the DLT was grade 3 diarrhea [71]. Preliminary findings from a phase II study evaluating neratinib at a dose of $240 \mathrm{mg} /$ day in patients with HER2-amplified trastuzumab-naïve or previously treated locally advanced breast cancer or MBC showed that patients in the previously treated group $(n=61)$ had an ORR of $26 \%$ with a median PFS of 23 weeks [72]. In the trastuzumab-naïve cohort, the ORR was $77 \%$ with a median PFS of 16 weeks. Diarrhea was the most common adverse event, and was present in $93 \%$ of patients with grade 3 toxicity and in $21 \%$ of patients with grade 4 toxicity.

Neratinib was combined with paclitaxel in advanced, previously treated HER2-positive MBC [73]. No DLT was encountered, and five out of 35 patients had PR. The most common grade 3 and grade 4 toxicities were diarrhea $(20 \%)$, neutropenia (9\%), and dehydration (2\%).

Neratinib and trastuzumab exert their effect on the HER2 receptor at various molecular sites, and it has been suggested that the combination of both agents may be synergistic. In a phase I/II study in patients with advanced HER2-positive breast cancer that had progressed after trastuzumab therapy, patients received $240 \mathrm{mg}$ neratinib with standard doses of trastuzumab [74]. The ORR was $27 \%$, which included $7 \%$ complete responses. The 16-week PFS rate was $45 \%$, and the median PFS duration was 19 weeks. No DLTs were observed, and diarrhea, nausea, anorexia, and vomiting were the most frequent adverse events.

Currently, three large phase III studies using neratinib are ongoing. A phase III, randomized study (NCT00777101) comparing neratinib with a combination of capecitabine and lapatinib in locally advanced breast cancer or MBC with HER2 amplification is under way. The primary objective of this study is to compare PFS in two regimens. Neratinib is also being compared with placebo in a phase III study of early-stage HER2-overexpressed breast cancer in patients who have been treated with trastuzumab (NCT00878709). Finally, a combination of neratinib plus paclitaxel is being compared with trastuzumab plus paclitaxel for the firstline treatment of HER2-positive locally advanced breast cancer or MBC (NCT00915018).

\section{Canertinib}

Canertinib (formerly known as CI-1033) is a smallmolecule TKI that potently inhibits all active members of the EGFR family. One important characteristic of canertinib is its property of irreversible inhibition through the ERB receptor, achieved by covalently modifying a cysteine residue in the ATP-binding site. Interestingly, this property determines canertinib's ability to induce ubiquitylation and degradation of both ErbB1 and ErbB2 [75], a property not shared by reversible TKIs.

In a phase I multicenter study [76], 32 patients with advanced solid malignancies received a starting dose of canertinib at $300 \mathrm{mg} /$ day; at a dose of $560 \mathrm{mg} /$ day, grade 3 DLT was observed in three of these patients. The maximum tolerated dose was declared at $450 \mathrm{mg}$, at which level one out of six patients experienced grade 3 dehydration associated with grade 2 stomatitis. Overall, gastrointestinal and skin toxicity were the most frequently reported adverse events. Efficacy analysis showed no objective response in 15 patients with measurable disease, and six patients had SD. Marked interpatient variability was found in 22 patients in the pharmacokinetic data, apparently not associated with the drug concentration in the plasma. 


\section{$E K B-569$}

EKB-569 has a molecule structure similar to that of neratinib. It is a potent inhibitor of EGFR with an $\mathrm{IC}_{50}$ of $39 \mathrm{nM}$ in an autophosphorylation assay, where it was substantially less active toward HER2 with an $\mathrm{IC}_{50}$ of 1,255 nM [77]. Results from a recent phase I doseescalation study using two different dose schedules have been reported [78]. Thirty patients were treated daily for 14 days of a 28-day cycle, and 29 patients received continuous daily dosing. The DLT was grade 3 diarrhea, and the maximum tolerated dose was $75 \mathrm{mg} /$ day. There were no objective responses, although 24 patients had SD for 8 weeks.

\section{Pertuzumab}

Pertuzumab is the first in a new class of agents known as HER dimerization inhibitors. Pertuzumab binds to HER2, the most common HER pairing partner, at the dimerization domain [79], inhibiting its ability to form dimers with other HER receptors [80,81]. The original findings from pertuzumab treatment in patients with solid tumors included good tolerance and clinical activity and supported a 3-week dosing schedule [82]. Interestingly, the pertuzumab binding site within domain II does not overlap with the epitope on HER2 that is recognized by trastuzumab, which allows combined targeting of both monoclonal antibodies against HER2. Preclinical data from studies combining pertuzumab and trastuzumab have shown that these two agents synergistically inhibit the survival of breast tumor cells [83]. The CB of this combination has been reported in patients with HER2 overexpression [84].

In preliminary findings from a phase II study of combined trastuzumab and pertuzumab in patients with HER2-overexpressed MBC, a 40\% CB rate with multiple complete responses and PRs was described [85].

\section{Ertumaxomab}

Ertumaxomab is a trifunctional bispecific antibody targeting HER2 on tumor cells and CD3 on T cells - that can redirect $\mathrm{T}$ cells, macrophages, dendritic cells, and natural killer cells to the sites of tumor metastases $[86,87]$.

\section{Antiangiogenic therapy: current and novel therapies}

Substantial preclinical and indirect clinical evidence suggests that angiogenesis plays an essential role in breast cancer development, invasion, and metastasis [88]. Angiogenesis is a fundamental mechanism in biology in which new blood vessels are formed from existing vasculature during a complex multistep process that is tightly regulated by proangiogenic factors and involves autocrine and paracrine signaling. Since VEGF is essential for the development of neovasculature at very early stages of tumorigenesis, it is believed to play a key role in the formation of tumor metastasis. The transition of a tumor from the avascular or prevascular phase to the vascular phase (increased growth and metastatic potential) is termed the angiogenic switch [89]. This switch - which is considered a hallmark of the malignancy process - is believed to be stimulated by increased expression of proangiogenic factors such as VEGF, basic fibroblast growth factor, and transforming growth factor $\beta$, and by decreased expression of antiangiogenic factors such as IFN $\alpha$ or thrompospondin-1 [90].

The VEGF-related gene family comprises six secreted glycoproteins: VEGF-A, VEGF-B, VEGF-C, VEGF-D, VEGF-E, placenta growth factor-1 and placenta growth factor-2 [91]. The past decade has witnessed major advances in the development of therapeutic agents that modulate tumor angiogenesis. Some of these agents have been shown to be effective in inhibiting tumor angiogenesis and have become an important part of standard cancer treatment: bevacizumab in colon, lung, breast, and renal cell carcinoma; sorafenib in renal cell carcinoma and hepatocellular carcinoma; and sunitinib in renal cell carcinoma and gastrointestinal stromal tumors.

\section{Bevacizumab}

Bevacizumab is derived from the murine VEGF monoclonal antibody A4.6.1 [92] and is composed of $\sim 93 \%$ human and $\sim 7 \%$ murine protein sequences. Experimental studies have showed that bevacizumab neutralizes all isoforms of human VEGF with a dissociation constant of $1.1 \mathrm{nmol} / \mathrm{l}$ [93]. Clinical pharmacology studies of bevacizumab have demonstrated a linear pharmacokinetics profile and a long terminal half-life of approximately 21 days (range, 11 to 50 days).

\section{Phase I/II studies of bevacizumab as a single agent and combined with chemotherapy}

Two phase I clinical trials of bevacizumab as a single agent in solid tumors have been reported. In the first trial, 25 patients with refractory solid tumors received doses of bevacizumab ranging from 0.1 to $10 \mathrm{mg} / \mathrm{kg}$ over 8 weeks [94]. In the second trial, bevacizumab was administered to 12 patients at a dose of $3 \mathrm{mg} / \mathrm{kg}$ in combination with chemotherapy [95]. These studies showed that bevacizumab is safe and without DLTs at doses up to $10 \mathrm{mg} / \mathrm{kg}$ and can be combined with chemotherapy, apparently without synergistic toxicity.

An early dose-escalation phase I/II clinical trial was conducted in 75 patients with MBC who were treated with bevacizumab to determine the agent's safety, efficacy, and pharmacokinetic characteristics [96]. Most of the patients (96\%) had received prior anthracycline-based or taxanebased chemotherapy for metastatic disease, and $28 \%$ of patients were HER2-positive. There were three different 
dose escalations at $3 \mathrm{mg} / \mathrm{kg}, 10 \mathrm{mg} / \mathrm{kg}$, and $20 \mathrm{mg} / \mathrm{kg}$ every 2 weeks. The ORR was $9.3 \%$ (confirmed response rate of $6.7 \%)$. The median duration of confirmed response was 5.5 months (range, 2.3 to 13.7 months). Four patients (5.3\%) discontinued the study treatment because of an adverse event. Hypertension was reported as an adverse event in $22 \%$ of patients. The optimal dose of bevacizumab in this trial was thus $10 \mathrm{mg} / \mathrm{kg}$ every other week, and toxicity was deemed to be acceptable.

\section{Phase III studies of bevacizumab in previously treated MBC}

Based on previous data, a phase III randomized trial was undertaken to evaluate bevacizumab treatment in women with heavily pretreated MBC [97]. In these patients, $\mathrm{MBC}$ had been previously refractory to anthracyclines and taxanes and had relapsed within the first 12 months of patients' completion of adjuvant therapy. A total of 462 patients were randomized to receive bevacizumab at $15 \mathrm{mg} / \mathrm{kg}$ every 3 weeks plus capecitabine at $2,500 \mathrm{mg} / \mathrm{m}^{2}$ in two divided doses for 2 weeks out of every 3 weeks, or capecitabine alone. The primary end point of the trial was PFS and was statistically identical between both arms (capecitabine, 4.2 months vs. capecitabine plus bevacizumab, 4.9 months). The ORR was significantly higher in the combination arm (19.8\%) than in the single-agent (capecitabine) arm (9.1\%; $P=0.001)$. The responses to bevacizumab tended to be short and were not translated into improved PFS duration, which was 4.9 months in the combination arm and 4.2 months in the single-agent (capecitabine) arm.

Phase III study of bevacizumab as first-line treatment for MBC The Eastern Cooperative Oncology Group 2100 trial enrolled 680 patients with previously untreated locally recurrent breast cancer or $\mathrm{MBC}$ [98]. Patients received weekly paclitaxel at $90 \mathrm{mg} / \mathrm{m}^{2}$ on days 1,8 , and 15 , with or without bevacizumab at $10 \mathrm{mg} / \mathrm{kg}$ on days 1 and 15 , in 4-week cycles until disease progression. All patients with HER2-positive disease were required to have received prior trastuzumab, and most (96\%) were HER2-negative. The primary end point of the study was PFS, which was significantly improved in patients who received the combination of bevacizumab plus paclitaxel versus single-agent paclitaxel (11.8 vs. 5.9 months; HR, 0.60; $95 \%$ CI, 0.43 to $0.62 ; P \leq 0.001$ ) (Figure 1 ). The PFS benefit with bevacizumab was observed across all subgroups, regardless of age, number of metastatic sites, previous adjuvant taxane use, disease-free interval after adjuvant therapy, and hormone receptor status. The ORR was $36.9 \%$ in the combination arm versus $21.2 \%$ in the singleagent paclitaxel arm $(P \leq 0.001)$. The safety profile of bevacizumab in the Eastern Cooperative Oncology Group 2100 trial, as reported in The New England Journal of Medicine [98], showed no increase in deaths; however, the trial was audited by a group of experts who found several cases of small-bowel perforation that the investigators had not attributed to bevacizumab. On 22 February 2008, the US Food and Drug Administration approved bevacizumab in combination with paclitaxel as first-line chemotherapy in patients with refractory $\mathrm{MBC}$.

A final OS report from the AVADO trial - a phase III placebo-controlled, randomized study of two doses of bevacizumab with or without docetaxel as first-line therapy for patients with recurrent or $\mathrm{MBC}$ - was presented at the San Antonio Breast Cancer Symposium (SABCS) 2009 [99]. An increase in PFS with docetaxel (100 mg/m² every 3 weeks) plus bevacizumab $(7.5 \mathrm{mg} / \mathrm{kg}$ or $15 \mathrm{mg} / \mathrm{kg}$ every week) was observed. In 736 patients, the drugs were analyzed for toxicity and efficacy. In terms of primary objective, the $\mathrm{HR}$ for docetaxel plus bevacizumab at $7.5 \mathrm{mg} / \mathrm{kg}$ was 0.80 (95\% CI, 0.65 to 1.00 ; $P=0.045)$ and for docetaxel plus bevacizumab at $15 \mathrm{mg} / \mathrm{kg}$ was 0.67 (95\% CI, 0.48 to $0.78 ; P=0.0002)$. The ORR was $46.4 \%$ for docetaxel and placebo, $55.2 \%$ for docetaxel and bevacizumab at $7.5 \mathrm{mg} / \mathrm{kg}$, and $64.1 \%$ for docetaxel and bevacizumab at $15 \mathrm{mg} / \mathrm{kg}$. Grade 3 and grade 4 adverse events were $67 \%$ for docetaxel and placebo, $74.8 \%$ for docetaxel and bevacizumab at $7.5 \mathrm{mg} / \mathrm{kg}$, and $74.1 \%$ for docetaxel and bevacizumab at $15 \mathrm{mg} / \mathrm{kg}$.

\section{Bevacizumab in combination with other targeted therapies}

A recent phase II clinical trial combined erlotinib and bevacizumab in patients with $\mathrm{MBC}$ who had received one or two prior chemotherapy regimens [100]. Thirtyeight patients were treated with erlotinib $(150 \mathrm{mg} /$ day orally) and bevacizumab (15 mg/kg intravenously every 3 weeks), and the primary end point was the response rate per Response Evaluation Criteria in Solid Tumors. Patients received a median of three cycles of treatment (range, 1 to 85 cycles). One patient (3\%) had PR after three cycles of therapy, and 15 patients (40\%) had SD at 9 weeks. The most common adverse events for the 38 patients were diarrhea $84 \%$ (grade 3 in only $3 \%$ ), rash $76 \%$ (grades 1 and 2 only), and fatigue 63\% (grades 1 and 2 only). Four patients (11\%) developed grade 3 hypertension that was controlled by oral medication, and eight patients (21\%) developed proteinuria. There were two grade 4 events: thrombosis and myalgias. Twenty-five patients were negative for EGFR tyrosine-kinase domain mutational analysis, and the level of EGFR expression was not predictive of response to therapy.

Mature data from five studies revealed improvement in PFS when bevacizumab was added to standard chemotherapy [98,99,101] (Table 2). The RIBBON-2 study became the first positive phase III study of bevacizumab in second-line MBC. Bevacizumab is currently being explored for use in early breast cancer, as neoadjuvant treatment in the NSABP B40 study, in TRN breast cancer 


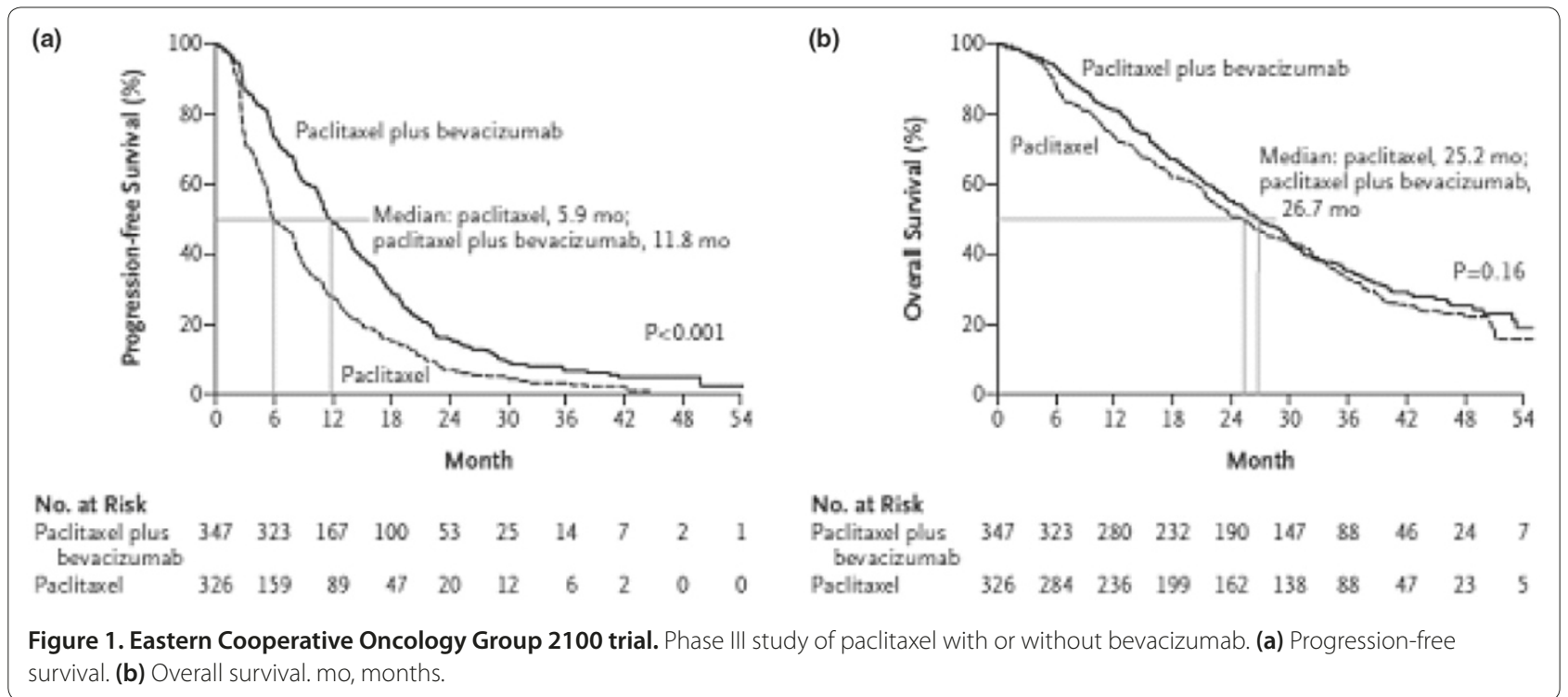

(BEATRICE study), and in HER2-positive disease as adjuvant treatment (BETH study).

\section{Emerging anti-VEGF therapies Tyrosine kinase inhibitors Sunitinib}

Sunitinib malate (formerly known as SU1128) is an oral TKI that targets several receptor tyrosine kinases, including VEGF receptor (VEGFR-1, VEGFR-2, and VEGFR-3), platelet-derived growth factor receptor (PDGFR- $\alpha$ and PDGFR- $\beta$ ), cKIT, and colony-stimulator factor 1 receptor [102]. In preclinical models, sunitinib administration resulted in significant reduction in phosphotyrosine levels of VEGFR-2, PDGFR- $\beta$, and KIT, which correlated with tumor growth inhibition. Treatment with sunitinib at 40 to $80 \mathrm{mg} / \mathrm{kg} /$ day (orally) displayed potent and broad-spectrum antitumor activity in mouse xenograft models, and resulted in inhibited growth in several human cell lines, including the breast cancer cell line MDA-MB-435 [103].

In one of the first studies of sunitinib in patients with solid tumors, the pharmacokinetic characteristics and safety were evaluated. A total of 28 patients received sunitinib orally for 4 weeks at doses ranging from 15 to 59 $\mathrm{mg} / \mathrm{m}^{2} /$ day (50 mg every other day to $150 \mathrm{mg} /$ day) [104].

Sunitinib was subsequently evaluated in a multicentric phase II trial in patients with MBC previously treated with anthracyclines and taxanes [105]. The primary trial objective was to determine the antitumor activity of sunitinib, starting at a dose of $50 \mathrm{mg}$ administered once daily for 4 weeks followed by 2 weeks off treatment, in repeated 6-week cycles. Sixty-four patients were included in the study; seven patients (11\%) achieved PR with a median duration of 19 weeks, and three patients (5\%) had
SD for 6 months, yielding a CB rate of 16\%. The median duration of response was 19 weeks, and the median time to tumor progression was 10 weeks. The overall probability of survival at 1 year was $41 \%$ (95\% CI, 28 to $54 \%$ ), and the median OS was 38 weeks (95\% CI, 28 to 63 weeks). Notably, responses occurred in three out of 20 patients (15\%) with TRN MBC, and in three out of 12 patients (25\%) with HER2-positive tumors. One-third of patients experienced grade 3 neutropenia, and all hematologic abnormalities resolved rapidly during off-treatment periods.

A preliminary report described the results of sunitinib combined with metronomic dosing of cyclophosphamide and methotrexate in patients with advanced breast cancer [106]. A total 15 patients were treated in three dose cohorts of sunitinib $(12.5 \mathrm{mg} /$ day, $25.0 \mathrm{mg} /$ day, and $37.5 \mathrm{mg} /$ day). Three patients developed grade 3 neutropenia and five patients developed mucositis. One patient had PR at week 14, and one patient had SD for 47 weeks. Enrollment for this study continues.

Findings from a preliminary report of a phase III study comparing sunitinib with capecitabine in previously treated HER2-negative MBC were recently presented at the SABCS 2009 [107]. A total of 482 patients had been randomized $1: 1$ to sunitinib $(37.5 \mathrm{mg} /$ day orally) and capecitabine $\left(1,000\right.$ to $1,250 \mathrm{mg} / \mathrm{m}^{2} /$ day orally from day 1 to 14 ), and the primary end point was PFS. The ORR and $\mathrm{CB}$ for patients treated with sunitinib were $11.3 \%$ and $19.3 \%$, and for those treated with capecitabine were $16.4 \%$ and $27 \%$, respectively (odds ratio, $0.65 ; 95 \% \mathrm{CI}, 0.4$ to 1.1). The PFS for patients treated with sunitinib and capecitabine was 2.8 months and 4.2 months, respectively (HR, 1.47; 95\% CI, 1.16 to $1.87 ; P=0.002$ ), and the OS duration was 15.3 months and 24.6 months, respectively (HR, 1.17; 95\% CI, 0.84 to $1.63 ; P=0.350$ ). 
Table 2. Phase III clinical studies incorporating bevacizumab to chemotherapy in breast cancer patients

\begin{tabular}{|c|c|c|c|c|c|c|c|}
\hline $\begin{array}{l}\text { Trial and } \\
\text { reference }\end{array}$ & $\begin{array}{l}\text { Number } \\
\text { of } \\
\text { patients }\end{array}$ & $\begin{array}{l}\text { Patient } \\
\text { population }\end{array}$ & $\begin{array}{l}\text { Bevacizumab } \\
\text { dose }\end{array}$ & $\begin{array}{l}\text { Combination } \\
\text { therapy }\end{array}$ & $\begin{array}{l}\text { End } \\
\text { point }\end{array}$ & $\begin{array}{c}\text { Benefit in } \\
\text { anti-VEGF } \\
\text { therapy }\end{array}$ & Study primary results \\
\hline $\begin{array}{l}\text { ECOG } 2100 \\
{[98]}\end{array}$ & 722 & First-line MBC & $\begin{array}{l}10 \mathrm{mg} / \mathrm{kg} \text { every } \\
2 \text { weeks }\end{array}$ & $\begin{array}{l}\text { P } 90 \mathrm{mg} / \mathrm{m}^{2} \text { days } \\
1,8,15\end{array}$ & PFS & Yes & $\begin{array}{l}\text { Bev and P significantly prolonged PFS compared } \\
\text { with } P \text { alone (median, } 11.8 \text { vs. } 5.9 \text { months; HR for } \\
\text { progression } 0.60, P<0.001) \text { and increased ORR } \\
\text { ( } 36.9 \% \text { vs. } 21.2 \% \text { ). No differences in OS between } \\
\text { two groups (median } 26.7 \text { vs. } 25.5 \text { months; } \\
\text { HR } 0.88, P=0.16 \text { ). Adverse effects: grade } 3 \\
\text { or } 4 \text { hypertension ( } 14.8 \% \text { vs. } 0 \%, P<0.001 \text { ), } \\
\text { proteinuria ( } 3.6 \% \text { vs. } 0 \%, P<0.001) \text {, headache } \\
\text { (2.2\% vs. } 0 \%, P=0.008) \text { and cerebrovascular } \\
\text { ischemia ( } 1.9 \% \text { vs. } 0 \%, P=0.02 \text { ) were more } \\
\text { common in patients receiving combination } \\
\text { treatment }\end{array}$ \\
\hline \multirow[t]{2}{*}{ AVADO [99] } & 736 & First-line MBC & $\begin{array}{l}7.5 \mathrm{mg} / \mathrm{kg} \\
\text { every } 3 \text { weeks }\end{array}$ & $\begin{array}{l}\text { D } 100 \mathrm{mg} / \mathrm{m}^{2} \\
\text { every } 3 \text { weeks }\end{array}$ & PFS & Yes & $\begin{array}{l}\text { In stratified analysis, patients receiving Bev had } \\
\text { significantly longer PFS compared with the D } \\
\text { monotherapy group (Bev at } 7.5 \mathrm{mg} / \mathrm{kg} \text { : median } \\
\text { PFS } 8.7 \mathrm{vs} .8 .0 \text { months, HR 0.79, } P=0.0318 \text {; Bev } \\
\text { at } 15 \mathrm{mg} / \mathrm{kg} \text { : median PFS } 8.8 \mathrm{vs} .8 .0 \text { months, } \\
\text { HR 0.72, P = 0.0099). ORR improved with the } \\
\text { addition of Bev (Bev } 7.5 \mathrm{mg} / \mathrm{kg}: 55 \% \text { vs. } 44 \%, P= \\
0.0295 ; \text { Bev } 15 \mathrm{mg} / \mathrm{kg}: 63 \% \text { vs. } 44 \%, P=0.0001 \text { ). } \\
\text { The study was not powered to find differences } \\
\text { in OS }\end{array}$ \\
\hline & & & $\begin{array}{l}15 \text { mg/kg every } \\
3 \text { weeks }\end{array}$ & & & & \\
\hline $\begin{array}{l}\text { RIBBON-2 } \\
{[102]}\end{array}$ & 684 & $\begin{array}{l}\text { Second-line } \\
\text { MBC }\end{array}$ & $\begin{array}{l}15 \text { mg/kg every } \\
3 \text { weeks }\end{array}$ & $\begin{array}{l}\text { Cap, taxanes } \\
\text { (Nab-Pac and D), } \\
\text { anthracycline, } \\
\text { Cap, gemcitabine, } \\
\text { vinorelbine }\end{array}$ & PFS & Yes & $\begin{array}{l}\text { Median PFS with Bev was } 7.2 \text { vs. } 5.1 \text { months (HR } \\
0.78, P=0.0072 \text { ). A trend for higher objective } \\
\text { response rate with Bev } 39.5 \% \text { vs. } 29.6 \% ; P= \\
0.013 \text {, not significant at prespecified } 0.01 \text {. No } \\
\text { difference in OS with combination therapy } \\
\text { compared with chemotherapy alone ( } 18 \text { vs. } \\
16.4 \text { months; HR } 0.90, P=0.3741 \text { ). Among the } \\
\text { different chemotherapy regimens used in the } \\
\text { trial, taxanes and Cap appeared to be more } \\
\text { effective, whereas gemcitabine and vinorelbine } \\
\text { appeared less effective }\end{array}$ \\
\hline $\begin{array}{l}\text { MO19391 } \\
{[103]}\end{array}$ & $2.027^{\mathrm{a}}$ & $\begin{array}{l}\text { HER2- MBC } \\
\text { or HER2+ if } \\
\text { previous Tz }\end{array}$ & $\begin{array}{l}10 \text { mg/kg every } \\
2 \text { weeks or } 15 \\
\text { mg/kg every } 3 \\
\text { weeks }\end{array}$ & $\begin{array}{l}\text { Taxane-based } \\
\text { chemotherapy }\end{array}$ & Safety & Yes & $\begin{array}{l}\text { Median follow-up was } 7.4 \text { months. } 75 \% \text { of } \\
\text { patients received taxanes, and } 25 \% \text { were treated } \\
\text { with nontaxane regimens (Cap and vinorelbine). } \\
\text { Safety and efficacy of Bev plus D or P was similar } \\
\text { to results of the E2100 and AVADO trials }\end{array}$ \\
\hline
\end{tabular}

Bev, bevacizumab; Cap, capecitabine; D, docetaxel; HER2, human epidermal growth factor receptor 2; HR, hazard ratio; MBC, metastatic breast cancer; Nab-Pac, Nab-paclitaxel; ORR, overall response rate; OS, overall survival; PFS, progression-free survival; P, paclitaxel; Tz, trastuzumab; VEGF, vascular endothelial growth factor. aCurrently enrolling patients.

One randomized phase III trial (SUN 1094) that included sunitinib as the experimental arm was recently closed because the primary end point could not be met. This study compared sunitinib plus paclitaxel with bevacizumab plus paclitaxel as a first-line metastatic regimen. Two large ongoing phase III trials are comparing sunitinib plus docetaxel with docetaxel (SUN 1064) in first-line $\mathrm{MBC}$ and comparing sunitinib plus 
capecitabine with capecitabine (SUN 1099) in secondline MBC.

\section{Sorafenib}

The developers of sorafenib (formerly known as BAY43-9006) have mainly focused on improving its activity against Raf- 1 kinase, which has an $\mathrm{IC}_{50}$ of $12 \mathrm{nM}$ both in vitro and in vivo [108]. Sorafenib has been evaluated in multiple phase I trials of refractory solid tumors. All trials identified hand-foot syndrome as the prominent DLT. Multiple trials using sorafenib in combination with chemotherapy have been reported [109]. For example, a two-stage, phase II, single-agent study in patients with $\mathrm{MBC}$ refractory to anthracyclines and taxanes was reported in which the initial dose was $400 \mathrm{mg}$ sorafenib twice daily and the primary end point was ORR [110]. Among 20 patients eligible for analysis of efficacy, one patient (5\%) achieved PR for 3.6 months. Because of a lack of sufficient response, the study was closed without proceeding to the second stage or accrual.

Two recent preliminary reports were presented at the SABCS 2009. In one randomized phase IIb study, which included 229 patients with locally advanced breast cancer or $\mathrm{MBC}$, patients had been treated with sorafenib plus capecitabine versus capecitabine (SOLTI-0701) [107]. In the combination arm, the median PFS increased from 4.1 to 6.4 months (HR, 0.576; $P=0.0006)$. These results represent a $42 \%$ reduction in the risk of disease progression or death. The ORR for the combination of sorafenib plus capecitabine was $38 \%$ and for capecitabine plus placebo was $31 \%(P=$ 0.1229 ). Adverse events were significantly higher in the combination arm, with hand-foot syndrome grade 3 seen in $45 \%$ versus $13 \%$ in the capecitabine plus placebo arm.

An international phase IIb study randomized 220 patients with locally advanced breast cancer or MBC to sorafenib plus paclitaxel versus paclitaxel as the first-line treatment [111]. Approximately, three-quarters of patients were accrued in India and $20 \%$ in the United States. Patients treated with the sorafenib and paclitaxel combination had a longer PFS (6.9 months) than did those in the single-agent paclitaxel arm (5.6 months) (HR, 0.788; $95 \%$ CI, 0.558 to $1.112 ; P=0.0857$ ). The ORR for patients treated with the combination or single-agent paclitaxel was $67 \%$ and $54 \%$, respectively $(P=0.023)$. Grade 3 adverse effects for hand-foot syndrome were $30 \%$ and $3 \%$ for the combination arm and single-agent paclitaxel, respectively. There was significant imbalance in regional patient characteristics with reference to age, hormone status, and prior chemotherapy, which made extracting solid conclusions from this trial difficult.

\section{Motesanib}

Motesanib (formerly known as AMG 706) is an orally administered multiple TKI of VEGF, platelet-derived growth factor, and KIT. Preclinical activity has been documented in multiple breast cancer cell lines. A 10-month analysis from the CIRG/TORI 010 trial was presented at the SABCS 2009 [112]. A total of 282 patients were randomized to one of three arms: motesanib plus paclitaxel, paclitaxel plus placebo, or paclitaxel plus bevacizumab. Patients were treated until progressive disease or intolerable toxicity, and the primary end point was ORR. Patients treated with motesanib plus paclitaxel had an ORR of $49.5 \%$, compared with $51.55 \%$ for patients treated with paclitaxel plus bevacizumab. The PFS was 9.49 months (range, 8.41 to 12.1 months) for the motesanib plus paclitaxel arm and 11.5 months (range, 9.3 to 15.4 months) for the paclitaxel plus bevacizumab arm. Hepatobiliary toxicity seen with motesanib emerged as a unique toxicity with an unknown etiology. Eight out of 92 patients in the motesanib arm (8.6\%) experienced grade 3 to 5 toxicity, including cholecystitis, gallbladder enlargement, cholestasis, and jaundice.

\section{Vandetanib}

Vandetanib (formerly known as ZD6474) inhibits two key pathways in tumor growth: VEGFR-dependent tumor angiogenesis, and EGFR-dependent tumor cell proliferation and survival. This compound is a potent inhibitor of kinase insert domain-contained receptor VEGFR-2 $\left(\mathrm{IC}_{50}=40 \mathrm{nM}\right)$, VEGFR-3 $\left(\mathrm{IC}_{50}=110 \mathrm{nM}\right)$, and EGFR/ HER1 $\left(\mathrm{IC}_{50}=500 \mathrm{nM}\right)$ [113]. Preclinical data have shown that the inhibition of EGFR signaling can inhibit the secretion of VEGF, as well as other proangiogenic factors such as basic fibroblast growth factor and transforming growth factor $\alpha$ [114]. The antitumor activity of vandetanib against EGFR may therefore reduce the levels of VEGF and other growth factors released by tumor cells. In a very elegant publication, Mi and Lou showed that vandetanib reversed p-glycoprotein-mediated multidrug resistance to Adriamycin, docetaxel, and vinorelbine in two p-glycoprotein-overexpressed breast cancer cell lines derived from MCF-7/Adriamycin and KBV200 [115]. In addition, this study suggested that vandetanib is not a substrate of p-glycoprotein.

In a phase I dose-escalation study of vandetanib in 77 patients with solid tumors [116], patients received oncedaily oral vandetanib (50 to $600 \mathrm{mg}$ daily) in 28-day cycles until disease progression or unacceptable toxicity. Pharmacokinetic analysis revealed a half-life of $\sim 120$ hours with significant interpatient variability. The study established that a dose of $300 \mathrm{mg}$ daily was well tolerated, and the most common DLTs were diarrhea, hypertension, and rash. Asymptomatic prolongation of the QT interval corrected for heart rate was more frequent with doses $>500 \mathrm{mg}$ daily.

In a phase II trial, Miller and colleagues treated 46 patients with $\mathrm{MBC}$ refractory to taxanes and 
anthracyclines [111]. The primary end point was ORR. The authors used a pharmacokinetic analysis from a previous phase I study that suggested potentially therapeutic levels of vandetanib would be achieved with both the $100 \mathrm{mg}$ and $300 \mathrm{mg}$ doses. Two patient cohorts were designated in this trial: those who initially received $100 \mathrm{mg}$ daily, and those enrolled later who received 300 mg daily in the absence of grade 3 or 4 prolongation of the QT interval corrected for heart rate. Forty-four patients who were evaluable for drug efficacy had no objective responses, and one patient had SD for longer than 24 months. The authors hypothesized that the lack of activity could be related to an inadequate blood concentration of vandetanib, although most patients achieved plasma concentration above the $\mathrm{IC}_{50}$; however, the common toxic effects for VEGF inhibitors (for example, hypertension, headache, and thrombosis) and for epidermal growth factor (severe rash) were not seen in this clinical study.

\section{Vatalanib}

Vatalanib (formerly known as PTK787/ZK 222584) is an oral inhibitor of VEGFR-1, VEGFR-2, and VEGFR-3 TKIs and other related kinases such as PDGFR- $\beta$, c-KIT, and cFms [112]. In vivo studies of vatalanib in mice showed that this agent significantly inhibited growth in many types of tumors and had the potential to inhibit metastasis [117]. Pharmacokinetic results for doses up to $1,000 \mathrm{mg} /$ day showed that vatalanib used once a day is rapidly absorbed, with a time of maximum concentration of 1.5 hours and a terminal half-life of about 3 to 6 hours [118].

In a view of vatalanib's short half-life, subsequent studies explored twice-a-day administration. A phase I study in patients with advanced solid tumors using doses of oral vatalanib at 150 to $1,000 \mathrm{mg}$ twice a day established that the maximum tolerated oral dose was $750 \mathrm{mg}$ twice a day, whereas the biologically activity dose was more than $1,000 \mathrm{mg}$ twice a day [119]. The DLT of reversible grade 3 lightheadedness was observed, along with dose-related grade 3 fatigue and vomiting. In phase I studies, promising antitumor activity was observed in patients with metastatic colorectal cancer.

\section{Farnesyltransferase inhibitors}

Our understanding of the molecular biology of Ras and its downstream pathways has grown considerably during the past decades. Ras proteins play a pivotal role in the transduction of cell growth-stimulating signals, and the mutation of the ras gene leads to constant activation of the protein, resulting in uncontrolled cell proliferation [120]. Point mutations in the ras proto-oncogene therefore result in permanently active Ras and are oncogenic. Although fewer than $5 \%$ of breast cancers have ras mutations, hyperactivation of the Ras protein in breast cancer has been described [121]. Rho proteins, downstream effectors of Ras, control cytoskeleton reorganization and gene expression. Overexpression of Rho was associated with locoregional and distant metastasis of breast cancer [122] and with inflammatory breast cancer [123].

Several compounds in preclinical and clinical trials have targeted various stages of the Ras signaling cascade, including inhibition of Ras expression via antisense oligodeoxynucleotides, interference via farnesyltransferase inhibitors, and inhibition of Ras downstream effectors via MEK, PI3K inhibitors, and others. The most advanced farnesyltransferase inhibitors currently in clinical development are tipifarnib and lorafarnib (SCH66336).

\section{Tipifarnib}

Tipifarnib (formerly known as R115777) is an imidazolecontaining heterocyclic compound that inhibits the growth of several wild-type and ras-mutated tumor cell lines and inhibits the growth of tumor xenografts in a dose-dependent manner, including wild-type ras MCF-7 breast cancer cells [124]. In phase I trials, tipifarnib has been administered at doses up to $1,300 \mathrm{mg}$ twice daily for 5 days every 2 weeks without significant toxicity [125]. In a phase II study of tipifarnib in patients with ER-positive $\mathrm{MBC}$ that progressed during second-line hormone therapy, 25\% of patients achieved CB [126].

Tipifarnib was combined with dose-dense doxorubicin and cyclophosphamide as neoadjuvant therapy for patients with locally advanced breast cancer, and seven out of 21 patients had a pathologic complete response [127]. These results are very encouraging because the pathologic complete responses occurred in ER-positive patients. In the recent publication of a phase II study in front-line therapy for MBC, tipifarnib combined with fulvestrant resulted in a CB rate of 51.6\% [128].

\section{Mammalian target of rapamycin inhibitors}

The PI3K signaling pathway is crucial to many key cellular functions, including growth, proliferation, survival, angiogenesis, and motility [129]. Aberrant activation of the pathway contributes to tumorigenesis, tumor metastases, and resistance to standard cancer therapy. In contrast to p53 and other tumor-suppressor pathways, the PI3K pathway is activated in cancer, making this an optimal target for therapy. PI3Ks are classified into three classes on the basis of their primary structure and substrate specificity: everolimus, sirolimus, and temsirolimus [130].

\section{Everolimus}

Everolimus (known as RAD-001) has greater polarity than sirolimus and was developed in an attempt to improve the pharmacokinetic characteristics of sirolimus, 
particularly to increase its oral bioavailability. Several studies showed that the most common toxicity observed with everolimus were diarrhea, asthenia, hyperglycemia, and anemia. A phase II, double-blind, randomized, placebo-controlled trial evaluated the value of adding everolimus to letrozole as primary systemic therapy [131]. The study showed that the combination of everolimus plus letrozole was associated with a higher ORR (68.1\% vs. $59.1 \%)$, which was confirmed by ultrasound (58\% vs. $47 \%$ ).

\section{Temsirolimus}

Temsirolimus (known as CCI-779) is a water-soluble ester of sirolimus. In preclinical studies, temsirolimus has demonstrated antitumor activity in breast cancer models [132]. In a phase I, dose/schedule-finding study in patients with advanced malignancies, 24 patients were treated with temsirolimus with doses ranging from 7.5 to $220 \mathrm{mg} / \mathrm{m}^{2}$ as a weekly intravenous infusion [133]. A DLT, thrombocytopenia, occurred in two patients at 34 or $45 \mathrm{mg} / \mathrm{m}^{2}$ and at $220 \mathrm{mg} / \mathrm{m}^{2}$. The most common related adverse events were dermatologic toxicity, and mucositis was seen in $71 \%$ of the patients. Other DLTs consisted of manic-depressive syndrome, stomatitis, and asthenia. All toxicities were reversible after treatment discontinuation. Two patients with renal cell carcinoma and breast cancer achieved PR.

In an international phase II study, patients previously treated for locally advanced breast cancer or $\mathrm{MBC}$ were randomized 1:1 to receive intravenous temsirolimus weekly at a dose of 75 or $250 \mathrm{mg}$ [134]. A total of 109 patients participated in the study. For at least 24 weeks (per Response Evaluation Criteria in Solid Tumors), CB was observed in $13.8 \%$ of patients; 10 patients had PR, and the ORR was $9.2 \%$. The most common adverse effects were mucositis (70\%), maculopapular rash (51\%), and nausea (43\%). Both doses showed antitumor activity, and $75 \mathrm{mg}$ generally resulted in a tolerable safety profile.

\section{Poly (ADP-ribose) polymerase inhibitors}

Poly (ADP-ribose) polymerase (PARP) 1 is a critical enzyme of cell proliferation and DNA repair. Multiple PARP-1 inhibitors have been tested preclinically as potentiators of chemotherapy and radiotherapy [135]. One function of PARP enzymes, particularly PARP-1 and PARP-2, is in the repair of single-stranded DNA breaks [136].

Given that BRCA1-related breast cancers generally have the same phenotypic expression profiles as BRCAnegative basal breast cancers, it has been hypothesized that sporadic TRN breast cancers may have a DNA repair deficit similar to that in BRCA-mutant cases. A randomized phase II study of BSI-201 in combination with gemcitabine plus carboplatin demonstrated that the combination prolonged both PFS and OS in TRN MBC
[137]. In total, 123 patients with TRN MBC were randomized to receive gemcitabine/carboplatin with or without BSI-201. Gene expression profiling performed primarily on breast cancer samples from 50 patients showed that PARP-1 expression was significantly upregulated $(P<0.0001)$. In the preliminary analysis, the CB rate was significantly better with BSI-201 plus gemcitabine/carboplatin than with gemcitabine/carboplatin alone ( $62 \%$ vs. $21 \%$, respectively; $P=0.0002)$, as were the ORR ( $48 \%$ vs. $16 \%$, respectively; $P=0.0001)$ and the median OS (9.2 vs. 5.7 months; $P=0.0005)$. There were no significant toxicity differences between treatment arms. The promising efficacy and low toxicity results have prompted the initiation of a phase III study.

Olaparib (AZD2281) is a novel PARP inhibitor with significant activity in patients with mutation of $B R C A 1 / 2$ breast cancer, ovarian cancer, or prostate cancer [131]. Preliminary results from a multicenter, open-label, phase II trial of olaparib in heavily pretreated patients with BRCA1/BRCA2-mutated advanced breast cancer were presented at the American Society of Clinical Oncology in 2009 [138]. This single-arm study included two sequential cohorts of patients: 27 patients who received $400 \mathrm{mg}$ olaparib twice daily and 27 patients who received $100 \mathrm{mg}$ twice daily. The ORR was $41 \%$ or $22 \%$ for those given $400 \mathrm{mg}$ or $200 \mathrm{mg}$, respectively. The cohort of patients treated with higher doses also showed improvement in other clinical end points: the median PFS time was longer with $400 \mathrm{mg}$ versus $200 \mathrm{mg}$ at 5.7 months versus 3.8 months, respectively, and most of the patients receiving $400 \mathrm{mg}$ twice daily experienced tumor shrinkage. There were no differences in toxicity between the two arms.

Several phase II studies using other PARP inhibitors (ABT-888, AGO14699, and MK4827) are also being investigated in early-stage trials.

\section{Conclusion}

The most recent major contribution to the treatment of breast cancer has not been a technical or pharmacological revolution, but rather a transformation in the way we think about the disease and the treatment. Biotechnology advances that facilitated the development of new therapeutic drugs were accompanied by an explosion of interest in the large-scale study of gene expression patterns. The development of new drugs in oncology, however, faces multiple challenges in the new molecular era. The continuous application of the old paradigm of traditional schemas of response to new targeted therapies may be inaccurate since neither tumor response nor toxicity is a useful surrogate for dose selection or efficacy. We need a better understanding of the molecular biology of signaling pathways and we need to discover new biomarkers in order to select optimal doses in phase II 
clinical studies. In addition, the selection of patients for targeted therapy remains a challenge because we presently lack reliable biomarkers to predict activity for most of the targeted agents.

\section{Abbreviations}

$C B$, clinical benefit; $C l$, confidence interval; DLT, dose-limiting toxicity; EGFR, epidermal growth factor receptor; ER, estrogen receptor; HER2, human epidermal growth factor receptor 2 ; $\mathrm{HR}$, hazard ratio; $I \mathrm{C}_{50^{\prime}}$, half-maximal inhibitory concentration; IFN, interferon; MBC, metastatic breast cancer; ORR, overall response rate; OS, overall survival; PARP, poly(ADP-ribose) polymerase; PDGFR, platelet-derived growth factor receptor; PFS, progression-free survival; PI3K, phosphatidylinositol-3-kinase; PR, partial response; SABCS, San Antonio Breast Cancer Symposium; SD, stable disease; TKI, tyrosine kinase inhibitor; TRN, triple receptor negative; VEGF, vascular endothelial growth factor; VEGFR, vascular endothelial growth factor receptor.

\section{Acknowledgements}

The author gratefully acknowledges Brenda McNaughton, Senior Administrative Assistant, for technical assistance, and Tamara K Locke, Scientific Editor, Scientific Publications, M.D. Anderson Cancer Center.

This article is part of Breast Cancer Research Volume 12 Supplement 2 Advanced breast cancer therapy. The full contents of the supplement are available online at http://breast-cancer-research.com/supplements/12/S2. Publication of this supplement has been sponsored by Bristol Myers Squibb Company. Translation services and administrative support were provided to the authors by Thomson Reuters, Healthcare and Science.

\section{Competing interests}

The author declares that he has no competing interests.

Published: 22 October 2010

\section{References}

1. Giordano C, Masi A, Pizzini A, Sansone A, Consalvi V, Chiaraluce R, Lucente G: Synthesis and activity of fibrillogenesis peptide inhibitors related to the 17-21 beta-amyloid sequence. Eur J Med Chem 2009, 44:179-189.

2. Fossati R, Confalonieri C, Torri V, Ghislandi E, Penna A, Pistotti V, Tinazzi A, Liberati A: Cytotoxic and hormonal treatment for metastatic breast cancer: a systematic review of published randomized trials involving 31,510 women. J Clin Oncol 1998, 16:3439-3460.

3. Cochrane Database System Reviews [http://www2.cochrane.org/reviews/ en/subtopics/52.html]

4. Group EBCTC: Tamoxifen for early breast cancer: an overview of the randomized trials. The Lancet 1998, 351:1451-1467.

5. Von Hoff DD, Layard MW, Basa P, Davis HL, Jr, Von Hoff AL, Rozencweig M, Muggia FM: Risk factors for doxorubicin-induced congestive heart failure. Ann Intern Med 1979, 91:710-717.

6. Jones LW, Haykowsky MJ, Swartz JJ, Douglas PS, Mackey JR: Early breast cancer therapy and cardiovascular injury. J Am Coll Cardio/ 2007, 50:1435-1441.

7. Lipshultz SE, Colan SD, Gelber RD, Perez-Atayde AR, Sallan SE, Sanders SP: Late cardiac effects of doxorubicin therapy for acute lymphoblastic leukemia in childhood. N Engl J Med 1991, 324:808-815.

8. Zambetti M, Moliterni A, Materazzo C, Stefanelli M, Cipriani S, Valagussa P, Bonadonna G, Gianni L: Long-term cardiac sequelae in operable breast cancer patients given adjuvant chemotherapy with or without doxorubicin and breast irradiation. J Clin Oncol 2001, 19:37-43.

9. Ganz PA, Hussey MA, Moinpour CM, Unger JM, Hutchins LF, Dakhil SR, Giguere JK, Goodwin JW, Martino S, Albain KS: Late cardiac effects of adjuvant chemotherapy in breast cancer survivors treated on Southwest Oncology Group protocol s8897. J Clin Oncol 2008, 26:1223-1230.

10. Sledge GW, Neuberg D, Bernardo P, Ingle JN, Martino S, Rowinsky EK, Wood WC: Phase III trial of doxorubicin, paclitaxel, and the combination of doxorubicin and paclitaxel as front-line chemotherapy for metastatic breast cancer: an intergroup trial (E1193). J Clin Oncol 2003, 21:588-592.

11. Jones S, Holmes FA, O'Shaughnessy J, Blum JL, Vukelja SJ, Mclntyre KJ, Pippen JE, Bordelon JH, Kirby RL, Sandbach J, Hyman WJ, Richards DA, Mennel RG, Boehm KA, Meyer WG, Asmar L, Mackey D, Riedel S, Muss H, Savin MA: Docetaxel with cyclophosphamide is associated with an overall survival benefit compared with doxorubicin and cyclophosphamide: 7-year follow-up of US Oncology Research Trial 9735. J Clin Oncol 2009, 27:1177-1183

12. Gianni L, Norton L, Wolmark N, Suter TM, Bonadonna G, Hortobagyi GN: Role of anthracyclines in the treatment of early breast cancer. J Clin Oncol 2009, 27:4798-4808.

13. Esteva FJ, Valero V, Pusztai L, Boehnke-Michaud L, Buzdar AU, Hortobagyi GN: Chemotherapy of metastatic breast cancer: what to expect in 2001 and beyond. Oncologist 2001, 6:133-146.

14. Bollag DM, McQueney PA, Zhu J, Hensens O, Koupal L, Liesch J, Goetz M, Lazarides E, Woods CM: Epothilones, a new class of microtubule-stabilizing agents with a taxol-like mechanism of action. Cancer Res 1995, 55:2325-2333.

15. Kamath K, Jordan MA: Suppression of microtubule dynamics by epothilone B is associated with mitotic arrest. Cancer Res 2003, 63:6026-6031.

16. Kolman A: Activity of epothilones. Curr Opin Investig Drugs 2005, 6:616-622.

17. Kowalski RJ, Giannakakou P, Hamel E: Activities of the microtubulestabilizing agents epothilones $A$ and $B$ with purified tubulin and in cells resistant to paclitaxel (Taxol(R)). J Biol Chem 1997, 272:2534-2541.

18. Wartmann M, Altmann $\mathrm{KH}$ : The biology and medicinal chemistry of epothilones. Curr Med Chem Anticancer Agents 2002, 2:123-148.

19. Nettles JH, Li H, Cornett B, Krahn JM, Snyder JP, Downing KH: The binding mode of epothilone $A$ on $a, \beta$-tubulin by electron crystallography. Science 2004, 305:866-869.

20. Lee FY, Borzilleri R, Fairchild CR, Kim SH, Long BH, Reventos-Suarez C, Vite GD, Rose WC, Kramer RA: BMS-247550: a novel epothilone analog with a mode of action similar to paclitaxel but possessing superior antitumor efficacy. Clin Cancer Res 2001, 7:1429-1437.

21. Cortes J, Baselga J: Targeting the microtubules in breast cancer beyond taxanes: the epothilones. Oncologist 2007, 12:271-280.

22. Roche H, Yelle L, Cognetti F, Mauriac L, Bunnell C, Sparano J, Kerbrat P, Delord JP, Vahdat L, Peck R, Lebwohl D, Ezzeddine R, Cure H: Phase II clinical trial of ixabepilone (BMS-247550), an epothilone B analog, as first-line therapy in patients with metastatic breast cancer previously treated with anthracycline chemotherapy. J Clin Oncol 2007, 25:3415-3420.

23. Denduluri N, Low JA, Lee JJ, Berman AW, Walshe JM, Vatas U, Chow CK Steinberg SM, Yang SX, Swain SM: Phase II trial of ixabepilone, an epothilone $B$ analog, in patients with metastatic breast cancer previously untreated with taxanes. J Clin Oncol 2007, 25:3421-3427.

24. Perez EA, Lerzo G, Pivot X, Thomas E, Vahdat L, Bosserman L, Viens P, Cai C, Mullaney B, Peck R, Hortobagyi GN: Efficacy and safety of ixabepilone (BMS-247550) in a phase II study of patients with advanced breast cancer resistant to an anthracycline, a taxane, and capecitabine. J Clin Oncol 2007 25:3407-3414.

25. Thomas ES, Gomez HL, Li RK, Chung HC, Fein LE, Chan VF, Jassem J, Pivot XB, Klimovsky JV, de Mendoza FH, Xu B, Campone M, Lerzo GL, Peck RA, Mukhopadhyay P, Vahdat LT, Roche HH: Ixabepilone plus capecitabine for metastatic breast cancer progressing after anthracycline and taxane treatment. J Clin Oncol 2007, 25:5210-5217.

26. Yarden Y, Sliwkowski MX: Untangling the ErbB signalling network. Nat Rev Mol Cell Biol 2001, 2:127-137.

27. Holmes WE, Sliwkowski MX, Akita RW, Henzel WJ, Lee J, Park JW, Yansura D, Abadi N, Raab H, Lewis GD, Shepard HM, Kuang WJ, Wood Wl, Goeddel DV, Vandlen RL: Identification of heregulin, a specific activator of p185erbB2. Science 1992, 256:1205-1210.

28. Carraway KL, 3rd, Cantley LC: A neu acquaintance for erbB3 and erbB4: a role for receptor heterodimerization in growth signaling. Cell 1994, 78:5-8.

29. Lewis TS, Shapiro PS, Ahn NG: Signal transduction through MAP kinase cascades. Adv Cancer Res 1998, 74:49-139.

30. Riese DJ, 2nd, Stern DF: Specificity within the EGF family/ErbB receptor family signaling network. Bioessays 1998, 20:41-48.

31. Harris AL, Nicholson S, Sainsbury JR, Farndon J, Wright C: Epidermal growth factor receptors in breast cancer: association with early relapse and death, poor response to hormones and interactions with neu. J Steroid Biochem 1989, 34:123-131.

32. Slamon DJ, Clark GM, Wong SG, Levin WJ, Ullrich A, McGuire WL: Human breast cancer: correlation of relapse and survival with amplification of the HER-2/neu oncogene. Science 1987, 235:177-182.

33. Baselga J, Norton L, Albanell J, Kim YM, Mendelsohn J: Recombinant humanized anti-HER2 antibody (Herceptin) enhances the antitumor 
activity of paclitaxel and doxorubicin against HER2/neu overexpressing human breast cancer xenografts. Cancer Res 1998, 58:2825-2831.

34. Cobleigh MA, Vogel CL, Tripathy D, Robert NJ, Scholl S, Fehrenbacher L, Wolter JM, Paton V, Shak S, Lieberman G, Slamon DJ: Multinational study of the efficacy and safety of humanized anti-HER2 monoclonal antibody in women who have HER2-overexpressing metastatic breast cancer that has progressed after chemotherapy for metastatic disease. J Clin Oncol 1999, 17:2639-2648.

35. Piccart-Gebhart MJ, Procter M, Leyland-Jones B, Goldhirsch A, Untch M, Smith I, Gianni L, Baselga J, Bell R, Jackisch C, Cameron D, Dowsett M, Barrios CH, Steger G, Huang CS, Andersson M, Inbar M, Lichinitser M, Lang I, Nitz U, Iwata H, Thomssen C, Lohrisch C, Suter TM, Ruschoff J, Suto T, Greatorex V, Ward C, Straehle C, McFadden E, et al:: Trastuzumab after adjuvant chemotherapy in HER2-positive breast cancer. N Engl J Med 2005, 353:1659-1672.

36. Buzdar AU, Ibrahim NK, Francis D, Booser DJ, Thomas ES, Theriault RL, Pusztai L, Green MC, Arun BK, Giordano SH, Cristofanilli M, Frye DK, Smith TL, Hunt KK, Singletary SE, Sahin AA, Ewer MS, Buchholz TA, Berry D, Hortobagyi GN: Significantly higher pathologic complete remission rate after neoadjuvant therapy with trastuzumab, paclitaxel, and epirubicin chemotherapy: results of a randomized trial in human epidermal growth factor receptor 2-positive operable breast cancer. J Clin Oncol 2005, 23:3676-3685.

37. Romond EH, Perez EA, Bryant J, Suman VJ, Geyer CE, Jr, Davidson NE, Tan-Chiu E, Martino S, Paik S, Kaufman PA, Swain SM, Pisansky TM, Fehrenbacher L, Kutteh LA, Vogel VG, Visscher DW, Yothers G, Jenkins RB, Brown AM, Dakhil SR, Mamounas EP, Lingle WL, Klein PM, Ingle JN, Wolmark N: Trastuzumab plus adjuvant chemotherapy for operable HER2-positive breast cancer. NEngl J Med 2005, 353:1673-1684

38. Fabian MA, Biggs WH, 3rd, Treiber DK, Atteridge CE, Azimioara MD, Benedetti MG, Carter TA, Ciceri P, Edeen PT, Floyd M, Ford JM, Galvin M, Gerlach JL Grotzfeld RM, Herrgard S, Insko DE, Insko MA, Lai AG, Lelias JM, Mehta SA, Milanov ZV, Velasco AM, Wodicka LM, Patel HK, Zarrinkar PP, Lockhart DJ: A small molecule-kinase interaction map for clinical kinase inhibitors. Nat Biotechnol 2005, 23:329-336.

39. Baselga J: Targeting the epidermal growth factor receptor: a clinical reality. J Clin Oncol 2001, 19:41S-44S.

40. Di Gennaro E, Barbarino M, Bruzzese F, De Lorenzo S, Caraglia M, Abbruzzese A, Avallone A, Comella P, Caponigro F, Pepe S, Budillon A: Critical role of both p27KIP1 and p21CIP1/WAF1 in the antiproliferative effect of ZD1839 ('Iressa'), an epidermal growth factor receptor tyrosine kinase inhibitor, in head and neck squamous carcinoma cells. J Cell Physiol 2003, 195:139-150.

41. Cristofanilli M, Schiff R, Valero V, lacona R, Yu J, Speake G, Smith I, Osborne CK: Exploratory subset analysis according to prior endocrine treatment of two randomized phase II trials comparing gefitinib $(G)$ with placebo $(P)$ in combination with tamoxifen ( $\mathrm{T}$ ) or anastrozole $(\mathrm{A})$ in hormone receptorpositive $\left(\mathrm{HR}^{+}\right.$) metastatic breast cancer (MBC). In: 2009 ASCO Annual Meeting. J Clin Oncol 2009, 27(Suppl 15):Abstract 1014.

42. PollackVA, Savage DM, Baker DA, Tsaparikos KE, Sloan DE, Moyer JD, Barbacci EG, Pustilnik LR, Smolarek TA, Davis JA, Vaidya MP, Arnold LD, Doty JL, I wata KK, Morin MJ: Inhibition of epidermal growth factor receptor-associated tyrosine phosphorylation in human carcinomas with CP-358,774: dynamics of receptor inhibition in situ and antitumor effects in athymic mice. J Pharmacol Exp Ther 1999, 291:739-748.

43. Twelves C, Trigo JM, Jones R, De Rosa F, Rakhit A, Fettner S, Wright T, Baselga J: Erlotinib in combination with capecitabine and docetaxel in patients with metastatic breast cancer: a dose-escalation study. Eur J Cancer 2008, 44:419-426.

44. Kaur H, Silverman P, Singh D, Cooper BW, Fu P, Krishnamurthy S, RemickS, Overmoyer B: Toxicity and outcome data in a phase I study of weekly docetaxel in combination with erlotinib in recurrent and/or metastatic breast cancer (MBC). In: 2006 ASCO Annual Meeting Proceedings Part I. $J$ Clin Oncol 2006, Suppl 18:Abstract 10623.

45. Venturini M, Catzeddu T, del Mastro L, Bighin C, Maggi E, Clavarezza M, Lunardi G, Pastorino S, Lambiase A, Rosso R: Erlotinib given sequentially to capecitabine and vinorelbine as first-second line chemotherapy in metastatic breast cancer patients. A does finding study. American Society of Clinical Oncology. In: 2004 ASCO Annual Meeting Proceedings. J Clin Oncol 2004, Suppl 14:Abstract 834.

46. Dickler M, Rugo HS, Caravelli J, Brogi E, Sachs D, Panageas K, Flores S, Moasser $M$, Norton L, Hudis C: Phase II trial of erlotinib (OSI-774), an epidermal growth factor receptor (EGFR)-tyrosine kinase inhibitor, and bevacizumab, a recombinant humanized monoclonal antibody to vascular endothelial growth factor (VEGF), in patients (pts) with metastatic breast cancer (MBC). In: 2004 ASCO Annual Meeting Proceedings. J Clin Oncol 2004, Suppl 14:Abstract 2001

47. Guix M, Granja Nde M, Meszoely I, Adkins TB, Wieman BM, Frierson KE, Sanchez V, Sanders ME, Grau AM, Mayer IA, Pestano G, Shyr Y, Muthuswamy S, Calvo B, Krontiras H, Krop IE, Kelley MC, Arteaga CL: Short preoperative treatment with erlotinib inhibits tumor cell proliferation in hormone receptor-positive breast cancers. J Clin Oncol 2008, 26:897-906.

48. Zha J, O'Brien C, Savage H, Huw LY, Zhong F, Berry L, Lewis Phillips GD, Luis E, Cavet G, Hu X, Amler LC, Lackner MR: Molecular predictors of response to a humanized anti-insulin-like growth factor-I receptor monoclonal antibody in breast and colorectal cancer. Mol Cancer Ther 2009, 8:2110-2121.

49. Beeram M, Burris HA, Modi S, Birkner M, Girish S, Tibbitts J, Holden SN, Lutzker SG, Krop IE: A phase I study of trastuzumab-DM1 (T-DM1), a first-in-class HER2 antibody-drug conjugate (ADC), in patients (pts) with advanced HER2 ${ }^{+}$breast cancer (BC). In: 2008 ASCO Annual Meeting. J Clin Oncol 2008, 26(Suppl 15):Abstract 1028

50. Vogel CL, Burris HA, Limentani S, Borson R, O'Shaughnessy J, Vukelja S, Agresta S, Klencke B, Birkner M, Rugo H: A phase II study of trastuzumabDM1 (T-DM1), a HER2, in patients (pts) with HER2 ${ }^{+}$metastatic breast cancer (MBC): final results. In: 2009 ASCO Annual Meeting. J Clin Oncol 2009, 27(Suppl 15):Abstract 1017.

51. Goldstein NI, Prewett M, Zuklys K, Rockwell P, Mendelsohn J: Biological efficacy of a chimeric antibody to the epidermal growth factor receptor in a human tumor xenograft model. Clin Cancer Res 1995, 1:1311-1318.

52. Cunningham D, Humblet Y, Siena S, Khayat D, Bleiberg H, Santoro A, Bets D, Mueser M, Harstrick A, Verslype C, Chau I, Van Cutsem E: Cetuximab monotherapy and cetuximab plus irinotecan in irinotecan-refractory metastatic colorectal cancer. N Engl J Med 2004, 351:337-345.

53. Modi S, D'Andrea G, Norton L, Yao TJ, Caravelli J, Rosen PP, Hudis C, Seidman AD: A phase I study of cetuximab/paclitaxel in patients with advancedstage breast cancer. Clin Breast Cancer 2006, 7:270-277.

54. Carey LA, Mayer E, Marcom PK, Rugo H, Liu M, Ma C, Rimawi M, Storniolo A, Forero A, Esteva F, Wolff A, Ingle J, Ferraro M, Sawyer L, Davidson N, Perou CM, Winer EP:TBCRC 001: EGFR inhibition with cetuximab added to carboplatin in metastatic triple-negative (basil-like) breast cancer. In: 30th Annual San Antonio Breast Cancer Symposium; San Antonio, TX. Breast Cancer Res Treat 2007, 106:Abstract 307.

55. O'Shaughnessy J, Weckstein DJ, Vukelja SJ, McIntyre K, Krekow L, Holmes FA, Asmar L, Blum JL: Preliminary results of a randomized phase II study of weekly irinotecan/carboplatin with or without cetuximab in patients with metastatic breast cancer. In: 30th Annual San Antonio Breast Cancer Symposium; San Antonio, TX. Breast Cancer Res Treat 2007, 106:Abstract 308

56. Burris HA, 3rd: Dual kinase inhibition in the treatment of breast cancer: initial experience with the EGFR/ErbB-2 inhibitor lapatinib. Oncologist 2004, 9(Suppl 3):10-15.

57. Wood ER, Truesdale AT, McDonald OB, Yuan D, Hassell A, Dickerson SH, Ellis B, Pennisi C, Horne E, Lackey K, Alligood KJ, Rusnak DW, Gilmer TM, Shewchuk L: A unique structure for epidermal growth factor receptor bound to GW572016 (Lapatinib): relationships among protein conformation, inhibitor off-rate, and receptor activity in tumor cells. Cancer Res 2004 64:6652-6659.

58. Rusnak DW, Affleck K, Cockerill SG, Stubberfield C, Harris R, Page M, Smith KJ, Guntrip SB, Carter MC, Shaw RJ, Jowett A, Stables J, Topley P, Wood ER, Brignola PS, Kadwell SH, Reep BR, Mullin RJ, Alligood KJ, Keith BR, Crosby RM, Murray DM, Knight WB, Gilmer TM, Lackey K: The characterization of novel, dual ErbB-2/EGFR, tyrosine kinase inhibitors: potential therapy for cancer. Cancer Res 2001, 61:7196-7203.

59. Xia W, Mullin RJ, Keith BR, Liu LH, Ma H, Rusnak DW, Owens G, Alligood KJ, Spector NL: Anti-tumor activity of GW572016: a dual tyrosine kinase inhibitor blocks EGF activation of EGFR/erbB2 and downstream Erk1/2 and AKT pathways. Oncogene 2002, 21:6255-6263.

60. Burstein HJ, Storniolo AM, Franco S, Forster J, Stein S, Rubin S, Salazar VM, Blackwell KL: A phase II study of lapatinib monotherapy in chemotherapyrefractory HER2-positive and HER2-negative advanced or metastatic breast cancer. Ann Oncol 2008, 19:1068-1074

61. Geyer CE, Forster J, Lindquist D, Chan S, Romieu CG, Pienkowski T, JagielloGruszfeld A, Crown J, Chan A, Kaufman B, Skarlos D, Campone M, Davidson N, Berger M, Oliva C, Rubin S, Stein S, Cameron D: Lapatinib plus capecitabine for HER2-positive advanced breast cancer. N Engl J Med 2006, 355:2733-2743. 
62. Konecny GE, Pegram MD, Venkatesan N, Finn R, Yang G, Rahmeh M, Untch M, Rusnak DW, Spehar G, Mullin RJ, Keith BR, Gilmer TM, Berger M, Podratz KC, Slamon DJ: Activity of the dual kinase inhibitor lapatinib (GW572016) against HER-2-overexpressing and trastuzumab-treated breast cancer cells. Cancer Res 2006, 66:1630-1639.

63. O'Shaughnessy J, Blackwell K, Burstein H, Storniolo AM, Sledge G, Baselga J, Koehler M, Laabs S, Florance A, Roychowdhury DF: A randomized study of lapatinib alone or in combination with trastuzumab in heavily pretreated HER2 ${ }^{+}$metastatic breast cancer progressing on trastuzumab therapy. In: 2008 ASCO Annual Meeting. J Clin Oncol 2008, 26:Abstract 1015.

64. Jones HE, Gee JM, Hutcheson IR, Knowlden JM, Barrow D, Nicholson RI: Growth factor receptor interplay and resistance in cancer. Endocr Relat Cancer 2006, 13(Suppl 1):S45-S51.

65. Nicholson RI, Hutcheson IR, Knowlden JM, Jones HE, Harper ME, Jordan N, Hiscox SE, Barrow D, Gee J: Non endocrine pathways and endocrine resistance: observations with antiestrogens and signal transduction inhibitors in combination. Clin Cancer Res 2004, 10:346S-354S

66. Chu QS, Cianfrocca ME, Goldstein LJ, Gale M, Murray N, Loftiss J, Arya N, Koch KM, Pandite L, Fleming RA, Paul E, Rowinsky EK: A phase I and pharmacokinetic study of lapatinib in combination with letrozole in patients with advanced cancer. Clin Cancer Res 2008, 14:4484-4490.

67. Johnston S, Pippen JE, Jr, Pivot X, Lichinitser M, Sadeghi S, Dieras V, Gomez H, Romieu G, Manikhas A, Kennedy J, Press MF, Maltzman J, Florance A, O'Rourke L, Oliva C, Stein S, Pegram M: Lapatinib combined with letrozole versus letrozole and placebo as first-line therapy for postmenopausal hormone receptor-positive metastatic breast cancer. J Clin Oncol 2009, 27:5538-5546.

68. Frassoldati A, Guarneri V, Piacentini F, Jovic G, Giovannelli S, Oliva C, Conte PF: Letrozole versus letrozole plus lapatinib (GW572016) in hormonesensitive, HER2-negative operable breast cancer: a double-blind, randomized, phase II study with biomarker evaluation (EGF109077LAP107692/LETLOB). Clin Breast Cancer 2008, 8:97-100.

69. Guarneri V, Frassoldati A, Piacentini F, Jovic G, Giovannelli S, Oliva C, Conte P: Preoperative chemotherapy plus lapatinib or trastuzumab or both in HER2-positive operable breast cancer (CHERLOB Trial). Clin Breast Cancer 2008, 8:192-194.

70. Tsou HR, Overbeek-Klumpers EG, Hallett WA, Reich MF, Floyd MB, Johnson BD, Michalak RS, Nilakantan R, Discafani C, Golas J, Rabindran SK, Shen R, Shi X Wang YF, Upeslacis J, Wissner A: Optimization of 6,7-disubstituted-4(arylamino)quinoline-3-carbonitriles as orally active, irreversible inhibitors of human epidermal growth factor receptor-2 kinase activity. J Med Chem 2005, 48:1107-1131.

71. Wong KK, Fracasso PM, Bukowski RM, Lynch TJ, Munster PN, Shapiro GI, Janne PA, Eder JP, Naughton MJ, Ellis MJ, Jones SF, Mekhail T, Zacharchuk C, Vermette J, Abbas R, Quinn S, Powell C, Burris HA: A phase I study with neratinib (HKI-272), an irreversible pan ErbB receptor tyrosine kinase inhibitor, in patients with solid tumors. Clin Cancer Res 2009, 15:2552-2558.

72. Burstein HJ, Sun Y, Tan AR, Dirix L, Vermette JJ, Powell C, Zacharchuk C, Badwe RA: Neratinib (HKI-272), an irreversible pan erbB receptor tyrosine kinase inhibitor: phase 2 results in patients with advanced $\mathrm{HER}^{+}$breast cancer. In Proceedings of the San Antonio Breast Cancer Symposium; San Antonio; 2008. 30th Annual San Antonio Breast Cancer Symposium, December 13-16 2007, San Antonio, TX

73. Chow L, Jiang Z, Epstein R, Bondarenko I, Awada A, Coughlin C, Gauthier E, Zhao Y, Abbas R, Hershman D: Safety and efficacy of neratinib (HKI-272) in combination with paclitaxel in patients with solid tumors. In: 2009 ASCO Annual Meeting. J Clin Oncol 2009, 27:Abstract 3557.

74. Swaby R, Blackwell K, Jiang Z, Sun Y, Dieras V, Zaman K, Zacharchuk C, Powell C, Abbas R, Thakuria M: Neratinib in combination with trastuzumab for the treatment of advanced breast cancer: a phase I/II study. In: 2009 ASCO Annual Meeting. J Clin Oncol 2009, 27(Suppl 15):Abstract 1004.

75. Citri A, Alroy I, Lavi S, Rubin C, Xu W, Grammatikakis N, Patterson C, Neckers L, Fry DW, Yarden Y: Drug-induced ubiquitylation and degradation of ErbB receptor tyrosine kinases: implications for cancer therapy. EMBO J 2002, 21:2407-2417.

76. Nemunaitis J, Eiseman I, Cunningham C, Senzer N, Williams A, Lenehan PF, Olson SC, Bycott P, Schlicht M, Zentgraff R, Shin DM, Zinner RG: Phase 1 clinical and pharmacokinetics evaluation of oral $\mathrm{Cl}-1033$ in patients with refractory cancer. Clin Cancer Res 2005, 11:3846-3853.

77. Torrance CJ, Jackson PE, Montgomery E, Kinzler KW, Vogelstein B, Wissner A, Nunes M, Frost P, Discafani CM: Combinatorial chemoprevention of intestinal neoplasia. Nat Med 2000, 6:1024-1028.
78. Erlichman C, Hidalgo M, Boni JP, Martins P, Quinn SE, Zacharchuk C, Amorusi P, Adjei AA, Rowinsky EK: Phase I study of EKB-569, an irreversible inhibitor of the epidermal growth factor receptor, in patients with advanced solid tumors. J Clin Oncol 2006, 24:2252-2260.

79. Franklin MC, Carey KD, Vajdos FF, Leahy DJ, de Vos AM, Sliwkowski MX: Insights into ErbB signaling from the structure of the ErbB2-pertuzumab complex. Cancer Cell 2004, 5:317-328.

80. Agus DB, Akita RW, Fox WD, Lewis GD, Higgins B, Pisacane PI, Lofgren JA, Tindell C, Evans DP, Maiese K, Scher HI, Sliwkowski MX: Targeting ligandactivated ErbB2 signaling inhibits breast and prostate tumor growth. Cancer Cell 2002, 2:127-137.

81. Sliwkowski MX, Schaefer G, Akita RW, Lofgren JA, Fitzpatrick VD, Nuijens A, Fendly BM, Cerione RA, Vandlen RL, Carraway KL, 3rd: Coexpression of erbB2 and erbB3 proteins reconstitutes a high affinity receptor for heregulin. J Biol Chem 1994, 269:14661-14665.

82. Agus DB, Gordon MS, Taylor C, Natale RB, Karlan B, Mendelson DS, Press MF Allison DE, Sliwkowski MX, Lieberman G, Kelsey SM, Fyfe G: Phase I clinical study of pertuzumab, a novel HER dimerization inhibitor, in patients with advanced cancer. J Clin Oncol 2005, 23:2534-2543.

83. Nahta R, Hung MC, Esteva FJ: The HER-2-targeting antibodies trastuzumab and pertuzumab synergistically inhibit the survival of breast cancer cells. Cancer Res 2004, 64:2343-2346.

84. Portera CC, Walshe JM, Rosing DR, Denduluri N, Berman AW, Vatas U, Velarde M, Chow CK, Steinberg SM, Nguyen D, Yang SX, Swain SM: Cardiac toxicity and efficacy of trastuzumab combined with pertuzumab in patients with [corrected] human epidermal growth factor receptor 2-positive metastatic breast cancer. Clin Cancer Res 2008, 14:2710-2716.

85. Gelmon K, Fumoleau P, Verma S, Wardley AM, Conte P, Miles D, Gianni L, McNally VA, Ross G, Baselga J: Results of a phase II trial of trastuzumab $(H)$ and pertuzumab $(P)$ in patients (pts) with HER2-positive metastatic breast cancer (MBC) who had progressed during trastuzumab therapy. In: 2008 ASCO Annual Meeting. J Clin Oncol 2008, 26:Abstract 1026.

86. Kiewe P, Hasmuller S, Kahlert S, Heinrigs M, Rack B, Marme A, Korfel A, Jager M, Lindhofer $\mathrm{H}$, Sommer $\mathrm{H}$, Thiel $\mathrm{E}$, Untch M: Phase I trial of the trifunctional anti-HER2 $x$ anti-CD3 antibody ertumaxomab in metastatic breast cancer. Clin Cancer Res 2006, 12:3085-3091.

87. Kiewe $P$, Thiel E: Ertumaxomab: a trifunctional antibody for breast cancer treatment. Expert Opin Investig Drugs 2008, 17:1553-1558.

88. Folkman J: What is the evidence that tumors are angiogenesis dependent? J Natl Cancer Inst 1990, 82:4-6.

89. Hanahan D, Folkman J: Patterns and emerging mechanisms of the angiogenic switch during tumorigenesis. Cell 1996, 86:353-364.

90. Dameron KM, Volpert OV, Tainsky MA, Bouck N: Control of angiogenesis in fibroblasts by $\mathrm{p} 53$ regulation of thrombospondin-1. Science 1994 265:1582-1584.

91. Ferrara N, Gerber HP, LeCouter J: The biology of VEGF and its receptors. Nat Med 2003, 9:669-676.

92. Kim KJ, Li B, Houck K, Winer J, Ferrara N: The vascular endothelial growth factor proteins: identification of biologically relevant regions by neutralizing monoclonal antibodies. Growth Factors 1992, 7:53-64.

93. Bucan M, Abrahams BS, Wang K, Glessner JT, Herman El, Sonnenblick LI, Alvarez Retuerto Al, Imielinski M, Hadley D, Bradfield JP, Kim C, Gidaya NB, Lindquist I, Hutman T, Sigman M, Kustanovich V, Lajonchere CM, Singleton A Kim J, Wassink TH, McMahon WM, Owley T, Sweeney JA, Coon H, Nurnberger Jl, Li M, Cantor RM, Minshew NJ, Sutcliffe JS, Cook EH, et al:: Genome-wide analyses of exonic copy number variants in a family-based study point to novel autism susceptibility genes. PLoS Genet 2009, 5:e1000536.

94. Gordon MS, Margolin K, Talpaz M, Sledge GW, Jr, Holmgren E, Benjamin R, Stalter S, Shak S, Adelman D: Phase I safety and pharmacokinetic study of recombinant human anti-vascular endothelial growth factor in patients with advanced cancer. J Clin Oncol 2001, 19:843-850.

95. Margolin K, Gordon MS, Holmgren E, Gaudreault J, Novotny W, Fyfe G, Adelman D, Stalter S, Breed J: Phase Ib trial of intravenous recombinant humanized monoclonal antibody to vascular endothelial growth factor in combination with chemotherapy in patients with advanced cancer: pharmacologic and long-term safety data. J Clin Oncol 2001, 19:851-856.

96. Cobleigh MA, Langmuir VK, Sledge GW, Miller KD, Haney L, Novotny WF, Reimann JD, Vassel A: A phase I/II dose-escalation trial of bevacizumab in previously treated metastatic breast cancer. Semin Oncol 2003, 30:117-124.

97. Miller KD, Chap LI, Holmes FA, Cobleigh MA, Marcom PK, Fehrenbacher L, Dickler M, Overmoyer BA, Reimann JD, Sing AP, Langmuir V, Rugo HS: 
Randomized phase III trial of capecitabine compared with bevacizumab plus capecitabine in patients with previously treated metastatic breast cancer. J Clin Oncol 2005, 23:792-799.

98. Miller K, Wang M, Gralow J, Dickler M, Cobleigh M, Perez EA, Shenkier T, Cella D, Davidson NE: Paclitaxel plus bevacizumab versus paclitaxel alone for metastatic breast cancer. N Engl J Med 2007, 357:2666-2676

99. Miles D, Chan A, Romieu G, Dirix L, Cortes J, Pivot X, Tomczak P, Taran T, Harbeck N, Steger GG: Randomized, double-blind, placebo-controlled, phase III study of bevacizumab with docetaxel or docetaxel with placebo as first-line therapy for patients with locally recurrent or metastatic breast cancer (mBC): AVADO. In: American Society of Clinical Oncology. J Clin Oncol 2008, 26:Abstract LBA 1011.

100. Dickler MN, Rugo HS, Eberle CA, Brogi E, Caravelli JF, Panageas KS, Boyd J, Yeh B, Lake DE, Dang CT, Gilewski TA, Bromberg JF, Seidman AD, D'Andrea GM, Moasser MM, Melisko M, Park JW, Dancey J, Norton L, Hudis CA: A phase II trial of erlotinib in combination with bevacizumab in patients with metastatic breast cancer. Clin Cancer Res 2008, 14:7878-7883.

101. Pierga J, Pritchard Kl, Thomssen C, Cortes-Funes H, Biganzoli L, Padrik P, Zvirbule Z, Smith I: Safety and efficacy of first-line bevacizumab (B) plus chemotherapy (CT) for locally recurrent or metastatic breast cancer (LR/ $\mathrm{mBC}$ ): analysis of MO19391 according to CT. In: 2009 ASCO Annual Meeting. J Clin Oncol 2009, 27(Suppl 15):Abstract 1033

102. Mendel DB, Laird AD, Xin X, Louie SG, Christensen JG, Li G, Schreck RE, Abrams TJ, Ngai TJ, Lee LB, Murray LJ, Carver J, Chan E, Moss KG, Haznedar JO, Sukbuntherng J, Blake RA, Sun L, Tang C, Miller T, Shirazian S, McMahon G, Cherrington JM: In vivo antitumor activity of SU11248, a novel tyrosine kinase inhibitor targeting vascular endothelial growth factor and plateletderived growth factor receptors: determination of a pharmacokinetic/ pharmacodynamic relationship. Clin Cancer Res 2003, 9:327-337.

103. Atkins M, Jones CA, Kirkpatrick P: Sunitinib maleate. Nat Rev Drug Discov 2006, 5:279-280

104. Faivre S, Delbaldo C, Vera K, Robert C, Lozahic S, Lassau N, Bello C, Deprimo S, Brega N, Massimini G, Armand JP, Scigalla P, Raymond E: Safety, pharmacokinetic, and antitumor activity of SU11248, a novel oral multitarget tyrosine kinase inhibitor, in patients with cancer. $J$ Clin Oncol 2006, 24:25-35.

105. Burstein HJ, Elias AD, Rugo HS, Cobleigh MA, Wolff AC, Eisenberg PD, Lehman M, Adams BJ, Bello CL, DePrimo SE, Baum CM, Miller KD: Phase Il study of sunitinib malate, an oral multitargeted tyrosine kinase inhibitor, in patients with metastatic breast cancer previously treated with an anthracycline and a taxane. J Clin Oncol 2008, 26:1810-1816.

106. Rugo HS, Lyandres J, Melisko M, Moasser M, Goga A, Scott J, Park J: Phase I study of sunitinib (S) in combination with metronomic dosing of cyclophosphamide and methotrexate (CM) in patients with metastatic breast cancer (MBC). Cancer Research 2008, 69(Suppl S):286S.

107. Baselga J, Segalla JGM, Roche H, del Giglio A, Ciruelos EM, Cabral Filho S, Gomez P, Lluch A, Llombart A, Costa F: SOLTI-0701: a double-blind, randomized phase $2 \mathrm{~b}$ study evaluating the efficacy and safety of sorafenib (SOR) compared to placebo (PL) when administered in combination with capecitabine (CAP) in patients (pts) with locally advanced (adv) or metastatic (met) breast cancer (BC). In: 34th ESMO Multidisciplinary Congress. Eur J Cancer Supp/ 2009, 7:3-4

108. Adnane L, Trail PA, Taylor I, Wilhelm SM: Sorafenib (BAY 43-9006, Nexavar), a dual-action inhibitor that targets RAF/MEK/ERK pathway in tumor cells and tyrosine kinases VEGFR/PDGFR in tumor vasculature. Methods Enzymol 2006, 407:597-612.

109. Rini BI: Sorafenib. Expert Opin Pharmacother 2006, 7:453-461.

110. Moreno-Aspitia A, Morton RF, Hillman DW, Lingle WL, Rowland KM, Jr, Wiesenfeld M, Flynn PJ, Fitch TR, Perez EA: Phase II trial of sorafenib in patients with metastatic breast cancer previously exposed to anthracyclines or taxanes: North Central Cancer Treatment Group and Mayo Clinic Trial N0336. J Clin Oncol 2009, 27:11-15.

111. Miller KD, Trigo JM, Wheeler C, Barge A, Rowbottom J, Sledge G, Baselga J: A multicenter phase II trial of ZD6474, a vascular endothelial growth factor receptor-2 and epidermal growth factor receptor tyrosine kinase inhibitor, in patients with previously treated metastatic breast cancer. Clin Cancer Res 2005, 11:3369-3376.

112. Wedge SR, Ogilvie DJ, Dukes M, Kendrew J, Chester R, Jackson JA, Boffey SJ, Valentine PJ, Curwen JO, Musgrove HL, Graham GA, Hughes GD, Thomas AP, Stokes ES, Curry B, Richmond GH, Wadsworth PF, Bigley AL, Hennequin LF: ZD6474 inhibits vascular endothelial growth factor signaling, angiogenesis, and tumor growth following oral administration. Cancer Res 2002, 62:4645-4655.

113. Ciardiello F, Caputo R, Bianco R, Damiano V, Fontanini G, Cuccato S, De Placido S, Bianco AR, Tortora G: Inhibition of growth factor production and angiogenesis in human cancer cells by ZD1839 (Iressa), a selective epidermal growth factor receptor tyrosine kinase inhibitor. Clin Cancer Res 2001, 7:1459-1465.

114. Mi Y, Lou L: ZD6474 reverses multidrug resistance by directly inhibiting the function of P-glycoprotein. Br J Cancer 2007, 97:934-940.

115. Holden SN, Eckhardt SG, Basser R, de Boer R, Rischin D, Green M, Rosenthal MA, Wheeler C, Barge A, Hurwitz HI: Clinical evaluation of ZD6474, an orally active inhibitor of VEGF and EGF receptor signaling, in patients with solid, malignant tumors. Ann Oncol 2005, 16:1391-1397.

116. Wood JM, Bold G, Buchdunger E, Cozens R, Ferrari S, Frei J, Hofmann F, Mestan J, Mett H, O'Reilly T, Persohn E, Rosel J, Schnell C, Stover D, Theuer A, Towbin H, Wenger F, Woods-Cook K, Menrad A, Siemeister G, Schirner M, Thierauch KH, Schneider MR, Drevs J, Martiny-Baron G, Totzke F: PTK787/ZK 222584, a novel and potent inhibitor of vascular endothelial growth factor receptor tyrosine kinases, impairs vascular endothelial growth factorinduced responses and tumor growth after oral administration. Cancer Res 2000, 60:2178-2189.

117. Drevs J, Hofmann I, Hugenschmidt H, Wittig C, Madjar H, Muller M, Wood J, Martiny-Baron G, Unger C, Marme D: Effects of PTK787/ZK 222584, a specific inhibitor of vascular endothelial growth factor receptor tyrosine kinases, on primary tumor, metastasis, vessel density, and blood flow in a murine renal cell carcinoma model. Cancer Res 2000, 60:4819-4824.

118. Drevs J, Zirrgiebel U, Schmidt-Gersbach Cl, Mross K, Medinger M, Lee L, Pinheiro J, Wood J, Thomas AL, Unger C, Henry A, Steward WP, Laurent D, Lebwohl D, Dugan M, Marme D: Soluble markers for the assessment of biological activity with PTK787/ZK 222584 (PTK/ZK), a vascular endothelial growth factor receptor (VEGFR) tyrosine kinase inhibitor in patients with advanced colorectal cancer from two phase I trials. Ann Oncol 2005, 16:558-565.

119. Thomas AL, Morgan B, Horsfield MA, Higginson A, Kay A, Lee L, Masson E, Puccio-Pick M, Laurent D, Steward WP: Phase I study of the safety, tolerability, pharmacokinetics, and pharmacodynamics of PTK787/ZK 222584 administered twice daily in patients with advanced cancer. $\int \mathrm{Clin}$ Oncol 2005, 23:4162-4171.

120. Friday BB, Adjei AA: K-ras as a target for cancer therapy. Biochim Biophys Acta 2005, 1756:127-144

121. O'Regan RM, Khuri FR: Farnesyl transferase inhibitors: the next targeted therapies for breast cancer? Endocr Relat Cancer 2004, 11:191-205.

122. Kleer CG, van Golen KL, Zhang Y, Wu ZF, Rubin MA, Merajver SD: Characterization of RhoC expression in benign and malignant breast disease: a potential new marker for small breast carcinomas with metastatic ability. Am J Pathol 2002, 160:579-584.

123. van Golen KL, Davies S, Wu ZF, Wang Y, Bucana CD, Root H, Chandrasekharappa S, Strawderman M, Ethier SP, Merajver SD: A novel putative low-affinity insulin-like growth factor-binding protein, LIBC (lost in inflammatory breast cancer), and RhoC GTPase correlate with the inflammatory breast cancer phenotype. Clin Cancer Res 1999, 5:2511-2519.

124. End DW, Smets G, Todd AV, Applegate TL, Fuery CJ, Angibaud P, Venet M, Sanz G, Poignet H, Skrzat S, Devine A, Wouters W, Bowden C: Characterization of the antitumor effects of the selective farnesyl protein transferase inhibitor R115777 in vivo and in vitro. Cancer Res 2001, 61:131-137.

125. Zujewski J, Horak ID, Bol CJ, Woestenborghs R, Bowden C, End DW, Piotrovsky VK, Chiao J, Belly RT, Todd A, Kopp WC, Kohler DR, Chow C, Noone M, Hakim FT, Larkin G, Gress RE, Nussenblatt RB, Kremer AB, Cowan KH: Phase I and pharmacokinetic study of farnesyl protein transferase inhibitor R115777 in advanced cancer. J Clin Oncol 2000, 18:927-941.

126. Johnston SR, Hickish T, Ellis P, Houston S, Kelland L, Dowsett M, Salter J, Michiels B, Perez-Ruixo JJ, Palmer P, Howes A: Phase II study of the efficacy and tolerability of two dosing regimens of the farnesyl transferase inhibitor, R115777, in advanced breast cancer. J Clin Oncol 2003, 21:2492-2499.

127. Sparano JA, Moulder S, Kazi A, Vahdat L, LiT, Pellegrino C, Munster P, Malafa M, Lee D, Hoschander S, Hopkins U, Hershman D, Wright JJ, Sebti SM: Targeted inhibition of farnesyltransferase in locally advanced breast cancer: a phase I and II trial of tipifarnib plus dose-dense doxorubicin and cyclophosphamide. J Clin Oncol 2006, 24:3013-3018.

128. LiT, Christos PJ, Sparano JA, Hershman DL, Hoschander S, O'Brien K, Wright JJ, 
Vahdat LT: Phase II trial of the farnesyltransferase inhibitor tipifarnib plus fulvestrant in hormone receptor-positive metastatic breast cancer: New York Cancer Consortium Trial P6205. Ann Oncol 2009, 20:642-647.

129. Hennessy BT, Smith DL, Ram PT, LuY, Mills GB: Exploiting the PI3K/AKT pathway for cancer drug discovery. Nat Rev Drug Discov 2005, 4:988-1004.

130. Cantley LC: The phosphoinositide 3-kinase pathway. Science 2002, 296:1655-1657.

131. Fong PC, Boss DS, Yap TA, Tutt A, Wu P, Mergui-Roelvink M, Mortimer P, Swaisland H, Lau A, O'Connor MJ, Ashworth A, Carmichael J, Kaye SB, Schellens JH, de Bono JS: Inhibition of poly(ADP-ribose) polymerase in tumors from BRCA mutation carriers. N Engl J Med 2009, 361:123-134.

132. Yu K, Toral-Barza L, Discafani C, Zhang WG, Skotnicki J, Frost P, Gibbons JJ: mTOR, a novel target in breast cancer: the effect of CCI-779, an mTOR inhibitor, in preclinical models of breast cancer. Endocr Relat Cancer 2001, 8:249-258.

133. Raymond E, Alexandre J, Faivre S, Vera K, Materman E, Boni J, Leister C, KorthBradley J, Hanauske A, Armand JP: Safety and pharmacokinetics of escalated doses of weekly intravenous infusion of CCl-779, a novel mTOR inhibitor, in patients with cancer. J Clin Oncol 2004, 22:2336-2347.

134. Chan S, Scheulen ME, Johnston S, Mross K, Cardoso F, Dittrich C, Eiermann W, Hess D, Morant R, Semiglazov V, Borner M, Salzberg M, Ostapenko V, Illiger HJ, Behringer D, Bardy-Bouxin N, Boni J, Kong S, Cincotta M, Moore L: Phase II study of temsirolimus (CCl-779), a novel inhibitor of mTOR, in heavily pretreated patients with locally advanced or metastatic breast cancer. J Clin Oncol 2005, 23:5314-5322.

135. Plummer ER: Inhibition of poly(ADP-ribose) polymerase in cancer. Curr Opin Pharmacol 2006, 6:364-368.

136. Schreiber V, Dantzer F, Ame JC, de Murcia G: Poly(ADP-ribose): novel functions for an old molecule. Nat Rev Mol Cell Biol 2006, 7:517-528.
137. O'Shaughnessy J, Osborne C, Pippen J, Yoffe M, Patt D, Monaghan G, Rocha C, Ossovskaya V, Sherman B, Bradley C: Efficacy of BSI-201, a poly (ADP-ribose) polymerase-1 (PARP1) inhibitor, in combination with gemcitabine/ carboplatin $(\mathrm{G} / \mathrm{C})$ in patients with metastatic triple-negative breast cancer (TNBC): results of a randomized phase II trial. In: 2009 ASCO Annual Meeting. J Clin Oncol 2009, 27(Suppl 18):Abstract 3.

138. Tutt A, Robson M, Garber JE, Domchek SM, Audeh MW, Weitzel JN, Friedlander M, Carmichael J: Phase II trial of the oral PARP inhibitor olaparib in BRCA-deficient advanced breast cancer. In: 2009 ASCO Annual Meeting. $J$ Clin Oncol 2009, 27(Suppl 18):Abstract CRA501.

139. Bunnell C, Vahdat L, Schwartzberg L, Gralow, J, Klimovsky, J, Poulart, V,Peck, R: Phase I/ll study of ixabepilone plus capecitabine in anthracycline pretreated/resistant and taxane-resistant metastatic breast cancer. Clin Breast Cancer 2008, 8:234-241.

140. Thomas E, Tabernero J, Fornier M, Conte P, Fumoleau P, Lluch A, Vahdat LT, Bunnell CA, Burris HA, Viens P, Baselga J, Rivera E, Guarneri V, Poulart V, Klimovsky J, Lebwohl D, Martin M: Phase II clinical trial of ixabepilone (BMS-247550), an epothilone B analog, in patients with taxane-resistant metastatic breast cancer. J Clin Oncol I2007, 25:3399-3406.

141. Low JA, Wedam SB, Lee JJ, Berman AW, Brufsky A, Yang SX, Poruchynsky MS, Steinberg SM, Mannan N, Fojo T, Swain SM: Phase II clinical trial of ixabepilone (BMS-247550), an epothilone B analog, in metastatic and locally advanced breast cancer. J Clin Oncol 2005, 23:2726-2734.

doi:10.1186/bcr2572

Cite this article as: Álvarez RH: Present and future evolution of advanced breast cancer therapy. Breast Cancer Research 2010, 12(Suppl 2):S1. 